=

Vestnik drevney istorii

81/2 (2021), 634-661

(C) The Author(s) 2021
Вестник древней истории

81/2 (2021), 634-661

(с) Автор(ы) 2021

DOI: $10.31857 / \mathrm{S} 032103910015606-9$

\title{
DATING TOMB G 1111 AT GIZA
}

\author{
Ivan V. Bogdanov \\ Institute of Oriental Manuscripts, Russian Academy of Sciences, Saint Petersburg, Russia \\ E-mail: jwan.bgd@yandex.ru
}

Until recently the provenance of the offering basin known through the transcription in Urk. I, 165 remained uncertain. On the basis of a photograph from the George Andrew Reisner's archive in the Museum of Fine Arts, Boston (Photo ID number: C10393_OS), it is possible to attribute to tomb G 1111 (Giza West Field). The present publication of the texts on the offering basin contains a number of corrections to the previous transcription by Kurt Sethe, as well as a commentary on the names and titles of the deceased and his son. Their names and titles show that both served as commanders of prospectors. A prosopography of all persons named $j w w-n m t j$ in the sources of the Old and Middle Kingdoms, as well as of the Old Kingdom holders of the office of shd srjw "inspector of prospectors", is compiled. In conclusion, it is suggested that the owner of the offering basin from tomb $\mathrm{G} 1111$ is identical with $j w w-n m t j$ mentioned in inscription Sinai 13, which dates to the reign of $d d-k 3-r^{\ulcorner} j z z j$. This is currently the earliest date for a tomb in Cemetery G 1100 at Giza established through indirect synchronism.

Keywords: Giza, Old Kingdom Egypt, Old Kingdom expeditions, Old Kingdom onomastics, Old Kingdom titles, Middle Kingdom onomastics

Domb G 1111 is located in south-east area of the northern part of cemetery G 1100 within the Giza West Field necropolis which is immediately adjacent to Cheops

Pyramid and is the largest cemetery at Giza.

According to architectural appearance, iconographic style of reliefs and statuary typologies, the earliest monuments of cemetery G 1100 date to the late $4^{\text {th }}$ or early $5^{\text {th }}$

Author. Ivan V. Bogdanov - PhD (History), Research fellow, Ancient Orient department, Institute of Oriental Manuscripts, Russian Academy of Sciences.

This article is a translation of: Богданов, И.В. К датировке гробницы G 1111 в Гизе. Journal of Ancient History [Vestnik drevney istorii] 81/2 (2021), 269-297. DOI: 10.31857/ S032103910014827-2.

I wish to express my sincere gratitude to my friend Dmitry O. Sychev who helped me in the completion of this study. 
Dynasties $^{1}$; however, most of the tombs of this group belong to the category of the secondary construction dated to the $6^{\text {th }}$ Dynasty. The evidence of titles does not make possible to identify any reliable criteria for dating tombs of this cemetery before the end of the $5^{\text {th }}$ Dynasty.

Epigraphy of the group of tombs G 1100 is modest and for the most part is not published. Porter \& Moss' Topographical Bibliography provides only selected data on the tombs and monuments from this cemetery ${ }^{2}$ :

G 1104 (statue of $z 3=j-m s(. j)$ ).

G 1105 (statue Cairo JdE37719³).

G 1109 (statue of $m r t-j b=j$ ).

G 1111 (offering basin, data reported in Porter \& Moss are incorrect; see further).

G 1151 (the owner is $n f r-k d=j$ ).

G 1152 (wooden statue of a boy, unnamed).

G 1157 (unnamed statue).

$\mathrm{G} 1171$ (the owner is $k 3=j-m$-t $n n t$ ).

All the materials found in tombs of cemetery G 1100 are now available on websites www.gizapyramids.org and giza.fas.harvard.edu. Here one can find archive photos of monuments from other tombs of this cemetery as well as those that were found on its territory. The following epigraphical materials should be added to the body of information presented in the Topographical Bibliography:

G 1105 and G 1107 (false door of $j h j$, found in the debris between these tombs) 4 .

G 1107 (offering table for a group of people: smsw pr «elder of the house» nfr, mrtrt (indicator of nobility for ladies, exact meaning is uncertain) $\check{s} p s t, z \breve{s}$ «scribe» $w p$, a woman named $r w \underline{d}-z 3 w=s$, a man named $\operatorname{prjw}(?)$; it contains a dedication by $h m-k 3 \ll k a$-servant» $k 3 j)^{5}$.

G 1119 (offering basin of $j j-{ }^{-} n h-n=f$, see further).

G 1123 (false door of $\left.t b 3 s^{5}\right)^{6}$.

G 1152a (false door lintel of $n j-k 3=j-m j n w)^{7}$.

G 1156 (false door of $p t h-h t p)^{8}$.

G $1162+1172$ B (false door of $t t j)^{9}$.

G 1165 (offering basin of $\underline{t} n t j$, see further).

${ }^{1}$ PM III.1 1974, 55-56. Statue Berkeley, Hearst Museum 6-19785 from tomb G 1109 dates to the end of the $4^{\text {th }}$ or the beginning of the $5^{\text {th }}$ Dynasties (Smith 1946, 62); this is the earliest dating for a monument from cemetery G 1100 . Tomb G 1111 is immediately adjacent to the large mastaba G 1020, statues from where also date to this period (Smith 1946, 61; PM III.1 1974, 53).

${ }^{2}$ PM III.1 1974, 55-56.

${ }^{3}$ www.gizapyramids.org: B11698_OS; B11697_OS; B11696_OS; EG010647. Hereinafter references made to website www.gizapyramids.org are cited with only Photo ID number. Reading the name of the owner of the statue is problematic: PM III.1 1974, 55: pt-pn-nswt; Fischer 1976, 23: «this nj-pt-nswt»; Scheele-Schweitzer 2014, 502 [2131]: Nzw-p.t-pn (?) «der König des Himmels ist er (?)».

${ }^{4}$ www.gizapyramids.org: B11757_OS; B13057-01_OS. Dating: 6th Dynasty (according to his title špsj nswt «royal nobleman»).

${ }^{5}$ www.gizapyramids.org: C10453 OS.

${ }^{6}$ www.gizapyramids.org: C12692_OS; B12984_OS; C12693_OS; AAW888.

${ }^{7}$ www.gizapyramids.org: B8584_NS.

${ }^{8}$ www.gizapyramids.org: B7619_NS.

${ }^{9}$ www.gizapyramids.org: C12034_OS; C11216_OS. 
$\mathrm{G} 1177$ (statue of $k 3=j-p w-p t h)^{10}$.

The bulk of attendants and officials buried at G 1100 cemetery were engaged in construction (G 1123, G 1105, G 1162+1172 B, G 1165) and organization of expeditions ( $G$ 1104, G 1111, G 1171). Two police titles (G 1171, G 1177), offices held in the corporation of $h n t j w-\breve{s}$ (G 1151, G 1152a) and some others, for example, the juridical one (G 1156), are also mentioned. Inscriptions in their tombs contain only a few important indicators for their dating. Most notable is titulary of $n f r-k d=j$, the owner of tomb G 1151, who held the office of $h m-n t r r r^{c} m \check{s} z p(w)-<j b>-r^{\complement}$ «priest of Ra in the Sun temple Desire of the Sun» ${ }^{11}$. However, this title of a functionary in the cult of the Sun temple of king $n j$ $w s r-r^{\top}$ cannot use as a reliable criterion for dating; according to other data tomb G 1151 should be dated later - to the second half of the $5^{\text {th }}$ Dynasty ${ }^{12}$. Moreover, $n f r-k d=j$ is the only known priest of Cheops ( $h m-n t r h w f w)$ buried in cemetery G 1100.

Inscriptions on the offering basin from tomb $\mathrm{G} 1111$ provide an opportunity to specify the date of development of cemetery G 1100 .

\section{OFFERING BASIN FROM TOMB G 1111}

First of all, it is necessary to once again clear up misunderstanding about attribution of offering basins Boston MFA 13.3282 and 13.3283 which finding place is sometime attributed to tomb G $1111^{13}$. This is incorrect. According to data from the archive of G.A. Reisner, offering basin Boston MFA 13.3282 comes from G 1165 which belonged to $t n t j^{14} . j j-{ }^{-} n h$ $n=f$ from tomb G $1119^{15}$ was the owner of another offering basin, Boston MFA 13.3283.

According to documents from the archive of G.A. Reisner, another offering basin was found in G 1111 for which the following reference was made ${ }^{16}$ : «Photo ID number:

${ }^{10}$ Cairo JdE37716. Fischer 1960, 301-302, fig. 2; www.gizapyramids.org: B11753_OS; C11955 OS.

${ }^{11} P \bar{M}$ III.1 1974, 56; the title is mentioned on the false door in situ in G 1151: www. gizapyramids.org: A6460_NS; A6478_NS, A6200_NS, A6458_NS. $n f r-k d=j$ also held the following titles: $r h n s w t(n) p r-?$ «king's acquaintance of the palace», $h m-n t r ~ h w f w$ «priest of

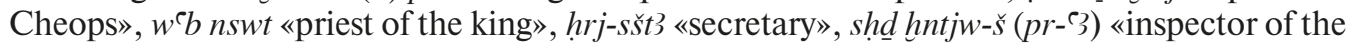

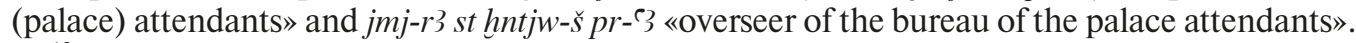

${ }^{12}$ Brovarski 2016, 86-87; cf. Nuzzolo 2018, 389-390 [74]: «Niuserre - Djedkare». A.M. Roth was inclined to identify him with $n f r-k d=j$, the owner of tomb G 2089 which she dated to the reigns of $n j-w s r-r^{\ulcorner}-j z z j$ (Roth 1995, 94-95), however this dating is highly doubtful.

13 PM III.1 1974, 55; Lehmann 1995, 27, 69.

${ }^{14}$ Lehmann 1995, Taf. 24; www.mfa.org/collections/object/offering-slab-140858; www. gizapyramids.org: C11990_OS. Dating: 6th Dynasty. There was a misunderstanding, probably because of a mistake in manuscript by G.A. Reisner who specified G 1111 as a place of discovery of offering basin of Tjenti (G 1165): Reisner, G.A. A History of the Giza Necropolis III. 1942 (unpublished manuscript). [Chap.] 17: [Analytic Overview of] Cemetery G 1000-1600: [Pt.] 7: Chronology of Cemetery G 1000-1600. [Pt.] VII. P. 034 (giza.fas.harvard.edu/photos/63607/full/: UM2901). Appendix G: Cemetery G 1000-1100. P. 015 (giza.fas.harvard.edu/photos/63676/full/: UM2970).

${ }^{15}$ www.gizapyramids.org: SC167191; see also: www.mfa.org/collections/object/offering-basin-ofiyankhenef-140860. Dating: late $6^{\text {th }}$ Dynasty. The origin of the offering basin is also mentioned in Reisner's documentation. Corrections of data from the PM III are presented on the website www.gizapyramids. org (Photo ID C11990_OS and SC167191) and on the website giza.fas.harvard.edu/sites/270/full/. See also Piacentini 2002a, $\overline{95}$, n. 3; 2002b, 334. The reading of the name as $j j-{ }^{-} n h=f$ is also likely.

${ }^{16}$ www.gizapyramids.org: C10393_OS; giza.fas.harvard.edu/ancientpeople/2881/full/. 
C10393_OS. Western Cemetery Giza; View: G 1111. Cemetery G «1100: G 1111, Photographer: George Andrew Reisner. Photo date: July 1904».

Photograph C10393_OS of the offering basin can be found on the websites www.gizapyramids.org and giza.fas.harvard.edu. Despite this publication, so far no one has paid attention to the offering basin, although this object is of interest for many reasons.

Epigraphy of the offering basin has long been available through K. Sethe's transcription in Urk. $\mathrm{I}^{17}$. According to Sethe, the text was copied by W. Spiegelberg in 1907 from an object seen at an antiquities dealer at Giza. Sethe himself made a transcription after Spiegelberg's estampage. The offering basin was entered into the Topographical Bibliography (Porter \& Moss) ${ }^{18}$ with reference to Urk. I and, as a result, actually remained non-attributed. At present it is exclusively quoted according to publication in Urk. $\mathrm{I}^{19}$.

According to the archive photograph C10393_OS, inscriptions on the offering basin from G 1111 basically correspond to the transcription published by Sethe in Urk. I, 165.

Thus, the offering basin was discovered by G.A. Reisner in July 1904, and already in 1907 it was seen by W. Spiegelberg at an antiquities dealer; that is within those three years the object was simply stolen from the excavation site at Giza or from the temporary storage and reach the antiquities market. I do not know the present location of this offering basin.

The photograph on the website www.gizapyramids.org clarifies Sethe's reading of the inscriptions. Corrections relate only to reading the name in the inscription on the left side of the offering basin (line 3) and the final part of the offering formula. Besides that, the title before the name on the right side is not reproduced in Urk. I at all.

\section{INSCRIPTIONS}

Transcription of the offering basin according to Urk. I, 165.4 and Urk. I, 165.8-10:

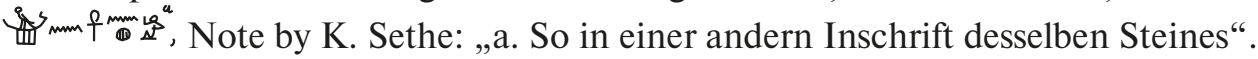

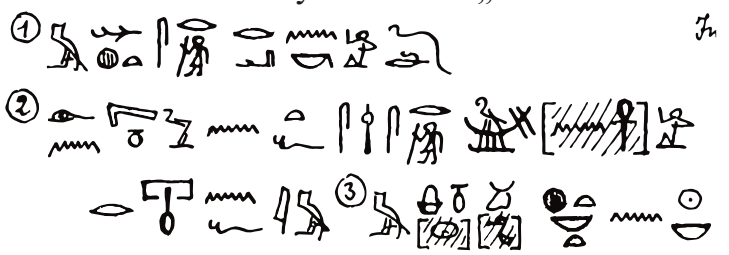

Transcription of the offering basin according to photograph C10393_OS published on the website www.gizapyramids.org:

\begin{tabular}{|c|c|}
\hline 1. Right side: & 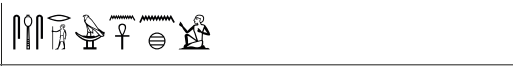 \\
\hline 2. Top: & 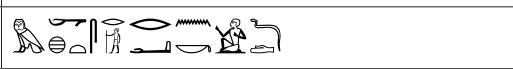 \\
\hline 3. Left side: & 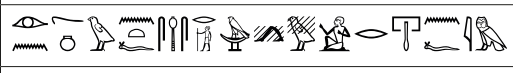 \\
\hline 4. Bottom: & $\stackrel{\theta \Theta}{\theta}$ \\
\hline
\end{tabular}

${ }^{17}$ Urk. I 1932-1933, 165.8-10.

${ }^{18}$ PM III.1 1974, 310.

${ }^{19}$ For example, Wilson 1947, 240; Strudwick 2005, 245-246; Hannig 2003, passim. 


\begin{tabular}{|c|c|}
\hline 1. shd $\operatorname{srjw} n j-{ }^{\ulcorner} n h=j-n m t j$ & 1. Inspector of prospectors $n j-\ulcorner n h=j-n m t j$. \\
\hline 2. jmj-hnt srjw $n j-k 3=j-r^{c} \underline{d} d(. j)$ & 2. Under-supervisor of prospectors $n j-k 3=j-r^{\ulcorner}$says: \\
\hline $\begin{array}{l}\text { 3. jrj.n=j nw } n \text { jt=j shd } \operatorname{srjw}[j] w(w)-n m t j(j) r \operatorname{pr}(t) n=f \\
h r w \text { jm }\end{array}$ & $\begin{array}{l}\text { 3. «I made this for my father, inspector of prospectors } \\
{[j] w(w)-n m t j \text {, that invocation offerings come forth for }} \\
\text { him therein, }\end{array}$ \\
\hline 4. $m t$ ḥnkt $k 3$ [3pd] (j)ht nb(t) bnrt $r^{\subset} n b$ & $\begin{array}{l}\text { 4. consisting of bread, beer, beef, [fowl], all sweet } \\
\text { things every day». }\end{array}$ \\
\hline
\end{tabular}

\section{Commentary on the offering formula}

Line 3. jrj. $n=j n w n j t=j \ldots(j) r \operatorname{pr}(t) n=f h r w j m$ «I made this for my father..., that invocation offerings come forth for him therein». One of the customary grammatical patterns of the formula prt-hrw «invocation offering» is presented here: in pseudo-verbal construction $(j) r \operatorname{pr}(t) h r w j m$ «that invocation offerings come forth therein» ${ }^{20}$. As it is known, this formula in the form $s \underline{d} m=f$ is represented by two patterns: $p r j=f h r w$ «he calls» (simple $s \underline{d} m=f$, structure: «he comes forth by the voice») and $\underline{d} j=f$ prj $h r w$ «he calls» (structure: «he gives so that the voice would come forth» is, in this case, analytic, compound causative build on the pattern $\underline{d} j=j r h=k$ «I inform you, I bring to your attention» which in Middle Egyptian was also used as subjunctive: «I would like to inform you; I have to tell you» ${ }^{21}$ ). In the first pattern the subject of «calling out» is a person while in the second pattern the voice itself is «coming forth». Such inversion of subjects of relationship for the verb prj «to come» is also reflected in the passive form $s \underline{d m} . t j=f:$ prj.tj $h r w$ «(someone is) calling» (structure: «(someone is) coming out by the voice»). The formula in the infinitive $p r(t) h r w$ is often used as a fixed expression which simply means «invocation, appeal» (to the deceased). Two directions of an action, however, still remain in its grammatical structure: it can be interpreted both as «coming forth by the voice» and as «coming forth of the voice». In our case the ritual appeal to the deceased is realized through inscriptions on the offering basin.

Line 4. (j)ht $n b(t) b n r t r^{\ulcorner} n b$ «...all sweet things every day». For a long time, this phrase has been considered the only example of plene spelling of the word $n b t$ «all, any» after $j h t$ «thing» in combination $(j) h t n b(t)$ «everything» that in the Old Kingdom always loses the ending $-t$ in the word $n b(t):$ Ө $^{22}$. Since this example was only written in Sethe's transcription in Urk. I, 165.10 , it has raised serious doubts ${ }^{23}$. The concerns proved justified: according to the photograph C10393_OS from Reisner archive, here isn't merely jht nbt «everything», but the combination $8{ }^{\circ . . .}(j) h t n b(t)$ bnrt «all sweet things» which is well known from the formulae on other monuments ${ }^{24}$. The feminine ending $-t$ in Sethe's transcription relates precisely to the word bnrt missed by him. Likewise, the preposition $n$ in the transcription in Urk. I, 165.10 should be corrected to determinative pl. «3 grains» for the word bnrt «sweet».

${ }^{20}$ Clère 1935-1938, 771-773; Barta 1968, 26; Lapp 1986, 91-110, § 155-326, in particular 97-104, § 168-184.

${ }^{21}$ About this form, also attested in Old Egyptian, see Luft 1984, 103-111.

${ }^{22}$ Edel 1955-1964, 50-51, § 113.

${ }^{23}$ Sperveslage 2010, 221, Anm. 20.

${ }^{24}$ For this component of the offering formula: Barta 1963, 169 (Index); Kaplony 1963, 970 (1505); Lapp 1986, 134-138, 252 (§ 235-241); Hannig 2003, 203-205 \{3691\}, 422 \{9875\}; Daoud 2005, 140, pl. 70; Legros 2013, 154-155, 157 (g); Kanawati 2013, 351, fig. 2, 359, etc. 


\section{Commentary on the names}

Three names are mentioned on the offering basin: $n j-{ }^{-} n h=j-n m t j,[j] w(w)-n m t j$ and $n j-k 3=j-r^{r}$.

Following Sethe, the name of the deceased in the third line of the declaration is traditionally restored as $\left[n j-{ }^{-} n h\right]-n m t j$ based of the perfectly preserved name $n j-{ }^{-} n h=j-n m t j$ in the first line (the right side). Nevertheless, as a matter of fact, this name is to be read as $[j] w(w)-n m t j$, which does not preclude from assuming that named on the right-hand shd $\underline{d}$ srjw «overseer of prospectors» $n j-{ }^{-} n h=j-n m t j$ is still identical with him. Turns out the owner of the offering basin had two names with the element $n m t j$, the name of the godwanderer, patron of travelers ${ }^{25}$.

Both anthroponyms with divine name $n m t j$ as a component are rare ${ }^{26}$.

1 . The name $n j-{ }^{-} n h=j-n m t j$ «my life belongs to the god $n m t j »$ is built according to typical Old Egyptian pattern $n j-\ulcorner h h=j-N N$ «my life belongs to (king or god) $\mathrm{NN}$ » or «NN owns my life». The following evidence of the name $n j-{ }^{\ulcorner} n h=j-n m t j^{27}$ are mentioned in the literature:

1.1. $\bar{y}^{\ominus}$. False door Stockholm, Medelhavsmuseet, $11406^{28}$. Hypocoristic: $n j^{29}$. Ti-

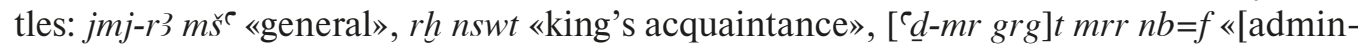
istrator of settlement], beloved by his lord», hrp w'bw nswt $3 h t$-[hwfw] «director of king's priests of the pyramid Horizon [of Cheops]». His eldest son and heir $\left(z 3=f s m s w j w w^{\complement} w=f\right)$ $j j-m$ - htp had similar titles: shd $\underline{d} w 3$ «captain (of crew) of the ship», hrp (j)m(jw)-z3 «director of the members of a phyle» ${ }^{30}$, $\underline{e}$ - $-m r$ grgt «administrator of settlement», hrp w'bw nswt «director of king's priests». According to the titles, both relatives served in the river fleet, organizing expeditions.

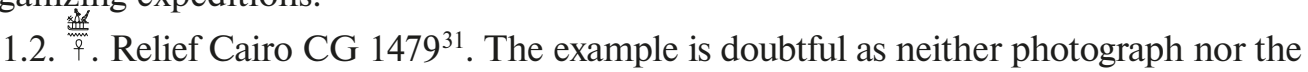
drawing of the inscription are published. This man was $h m-k 3$ «funerary priest» of $r n-(j) r j$, father of leather worker $w t 3$. H. Ranke read his name as $n j-{ }^{-} n h-z k r^{32}$. K. Scheele-Schweitzer gives a combined reading $N(. j)$ - ${ }^{-} n h-h n . w / N m . t j$ «Besitzer von Leben ist die $h n . w$-Barke/Nemti» with a note: «M.E. ist die Lesung als $N(. j)-{ }^{-} n h-N m . t j$ hier zu bevorzugen» ${ }^{33}$. Doubts about the name reading are related to multiple meaning of sign given by $\mathrm{L}$. Borchardt, which is open to different readings: $n m t j, z k r$, or $h n w$ «Sokar's boat» ${ }^{34}$. The reading $n j-{ }^{`} n h=j-z k r \ll$ my

${ }^{25}$ About the god $n m t j$ see Berlev 1969, 3-30; Graefe 1980, 1-27, 43-46, 49; Leitz 2002, 242-244.

${ }^{26}$ For the Old Kingdom names with the component $n m t j$ : Ranke 1935, 69-70; 1952, 36. Bland, Malek 1977, 119-120; Thirion 1985, 142; Scheele-Schweitzer 2014, Nr. [173], [765], [913], [1364], [1546], [1553], [1612], [1652], [1904], [1934], [1968], [2065]-[2068], [2585], [2723], [3311].

${ }^{27}$ Bland, Malek 1977, 119-120; Scheele-Schweitzer 2014, 419 [1546].

${ }^{28}$ PM III.1 1974, 137; Junker 1943, 239-240, Abb. 101 (collections.smvk.se/carlotta-mhm/ web/object/3016006). Dating: late $4^{\text {th }}-$ early $5^{\text {th }}$ Dynasty. Giza West Field.

${ }^{29}$ Scheele-Schweitzer 2014, 449 [1740].

${ }^{30}$ For this title: Bogdanov 2018, 236, n. 60.

${ }^{31}$ Door jamb Cairo JdE30186: PM III.1 1974, 309; Borchardt 1937, 166 (without photograph). Dating: late $4^{\text {th }}$ Dynasty. On the dating the relief see also Diego Espinel 2014, 46-48 (late $4^{\text {th }}-$ early $5^{\text {th }}$ Dynasty).

32 Ranke 1952, 294.4.

${ }^{33}$ Scheele-Schweitzer 2014, 421 [1553], Anm. 48.

34 Thirion 1985, 126. 
life belongs to Sokar ${ }^{35}$ is based only on credence to Borchardt's transcription; if it is right, then the sign is the ideographic name of the god Sokar. However, Sokar's name was not written with a single ideogram like $h n w$, so $n m t j$ is the preferred reading.

1.3. On the offering basin published in Urk. I, 165 which is the subject of this study.

Thus, there are only two reliable evidences for the name $n j-{ }^{-} n h=j-n m t j$ in the Old Kingdom, and one of them is preserved exactly on the offering basin from G 1111 .

2. Name $j w w-n m t j$ occurs more often, it has been attested both in the $\mathrm{Old}^{36}$ and the Middle Kingdoms. By a strange coincidence it is not listed in H. Ranke's Personennamen. Scheele-Schweitzer's Handbuch cites the following data on this anthroponym:

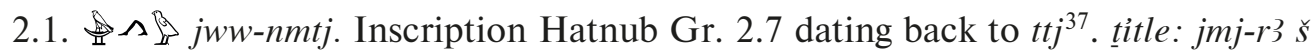
«overseer of the lake (i.e. the contingent of soldiers and craftsmen and their locations)» ${ }^{38}$. The reading of the name is doubtful. Hieratic original after G. Möller's copy: $\frac{\pi}{\Delta}$.

2.2. $\wedge j w w-n m t j$. Inscription Hatnub Gr. 3.2 dated to «year of the $14^{\text {th }}$ occasion (of the counting)» i.e. $27 / 28^{\text {th }}$ regnal year of king $h r n t r j-h^{\complement} w$ (ppj II) ${ }^{39}$. Title: htmtj-ntr «treasurer of the god». He was the expedition chief and the author of the inscription. His identity with the first $j w w-n m t j$ who lived during the reigns of $t t j$ is hardly possible as two graffiti are separated by 27 years.

2.3. $\wedge$ sww-nmtj. Inscription in Wadi Maghara ${ }^{40}$. Title: $j m j-r 3 s r(j w)$ «overseer of prospectors». It dates back to rnpt $m$ - ht $z p 4$ tnwt jhw ` $w t ~ n b$ «year after the $4^{\text {th }}$ occasion of the counting all the large and small cattle», i.e. 8th/9th regnal year of king $\underline{d} d-k 3-r^{\ulcorner} j z z j$.

2.4. $\wedge j w w-n m t j$. The name is attested on one or two figurines from the series of socalled Execration texts of the Old Kingdom ${ }^{41}$. Altogether, four pots with the Execration texts containing 435 names of rebellious Nubians and Egyptians (some of them duplicated) were discovered at Giza. Dating marks going back to year $(m)-h t z p-5$ «after the $5^{\text {th }}$ occasion (of the counting)» i.e. to $10^{\text {th }} / 11^{\text {th }}$ regnal year of unknown king remained on three pots, and namely:

${ }^{35}$ Ranke 1935, 172.1; 298.9 (?); Scheele-Schweitzer 2014, 424 [1564], 630 [2987] (?).

${ }^{36}$ Scheele-Schweitzer 2014, 222 [173].

${ }^{37}$ Anthes 1928, 19, Taf. 9.

${ }^{38}$ About this title: Bogdanov 2019, 137, n. 109. Translation of Graffito 6 from Gebel elSilsila which was published with low-quality photograph, incorrect transcription and faulty transliteration (Graffito 6. GeSW.RIS.9: Nilsson, Faraman, Said 2018, 78) is also given here. However, previously published translation of this inscription (Osing 2004, 5) was not taken into account either by the publishers or me. Given the J. Osing's article I made a new, slightly corrected translation, although it as well does not purport to be accurate until a quality publication

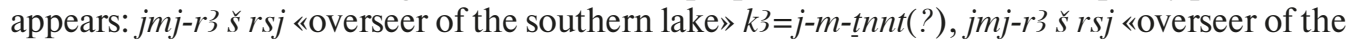
southern lake» hnzw-htp, hrjj-` smntjw 260 (?) «under (their) supervision: 260 (?) guides» (only from photograph, transcription is missing), jmj-r $r 3$ s $m h t j$ «overseer of the northern lake» ${ }^{C} n h-m-{ }^{-}-r{ }^{r}$, $h r p$ ¿ $p r \check{s} r s j$ «captain of a squad of the southern lake» nfr-sšm-pth, žs $\breve{s}$ «scribe of the lake» mrw.

${ }^{39}$ Anthes 1928, 20, Taf. 10.

${ }^{40}$ Inscription Sinai 13: Weill 1904, 109-116 (11-12); Urk. I 1932-1933, 56.6-8; Gardiner, Peet, Černý 1952, pl. 7; Baines, Parkinson 1997, 9-27, fig.1; Tallet 2018, 304.

${ }^{41}$ Abu Bakr, Osing 1973, 107 (AB100), Taf. 42-43; Osing 1976a, 139 (RB83), Taf. 44 (doubtful). 
1. Pot of series AB: (m)-ht zp 5 3bd 3 prt hrw 29 «year after the $5^{\text {th }}$ occasion (of the counting), $3^{\text {rd }}$ month of the seed season, $29^{\text {th }}$ day» ${ }^{42}$;

2. Pot of series J: $(m)-h t z p-53 b d 3$ prt hrw 22 «year after the $5^{\text {th }}$ occasion (of the counting), 3rd month of the seed season, $22^{\text {nd }}$ day» ${ }^{43}$;

3. Pot of series RK: $(m)$-ht zp 5 3bd 2 prt hrw 5 «year after the $5^{\text {th }}$ occasion (of the counting), 2 nd month of the seed season, $5^{\text {th }}$ day» ${ }^{44}$.

According to these data the ritual, in the course of which the pots were buried, lasted over 55 days (from at least $3 b d 2$ prt hrw $5 \ll 5^{\text {th }}$ day of $2^{\text {nd }}$ month of the seed season» to $3 b d 3$ prt hrw 29 «29 $29^{\text {th }}$ day of $3^{\text {rd }}$ month of the seed season»). I think that burial of the figurines with the names of Nubian rebels at Giza was the result of the punitive campaign of king $m r j . n-r^{r}$ to Nubia which was accomplished in his $9^{\text {th }} / 10^{\text {th }}$ regnal year. Campaign rock inscriptions, devoted to that event, contain the following dates from the reign of $m r j . n-r^{r^{45}}:$ zp 5 tnwt $3 b d 2$ smw hrw 24 «year of the $5^{\text {th }}$ occasion of the counting, $2^{\text {nd }}$ month of the harvest season, $25^{\text {th }}$ day» ${ }^{46}$, and zp 5 tnwt $3 b d 2 \check{s} m w$ hrw 28 «year of the $5^{\text {th }}$ occasion of the counting, $2^{\text {nd }}$ month of the harvest season, $28^{\text {th }}$ day» ${ }^{47}$. If one accepts dating of the figurines with the Execration texts to the reign of $m r j . n-r^{c}$, that means that they were made 6-8 months later than the above-mentioned graffiti ${ }^{48}$. During that period of time (between $2^{\text {nd }}$ month of the harvest season of year of the $5^{\text {th }}$ occasion of the counting and $2^{\text {nd }}$ month of the seed season of year after the $5^{\text {th }}$ occasion of the counting) king $m r j . n-r^{c}$ reached Nubia, defeated rebels, drew up a list of those who had been slain or executed, came back and performed the rite of burying the pots with the figurines of the rebels at Giza. The name $j w w-n m t j$ is typical exactly for the expedition members; thus, that military man or prospector repeatedly visited Nubia in the line of duty. Most of the rebels, listed on the occasion of their rebellion suppression, had Nubian names ${ }^{49}$, and only a few dozen held Egyptian names ${ }^{50}$, at that Nubians with Egyptian names were singled out

${ }^{42}$ Abu Bakr, Osing 1973, 131, Taf. 31-32. The earliest case of spelling of the word «day of month» in the form $z j w / z w(\mathrm{~Wb}$. IV, 57.8-58.1; Meeks 1998, I, 309, 77.3422) dates back to the $11^{\text {th }}$ Dynasty (stela of rdjw-hnmw: Cairo CG 20543, line 14 (Lange, Schäfer 1908, 166). Dendera; cf. Schenkel 1965, 113, Anm. i); possibly, this word was derived from verb $z j$ «pass on» and initially sounded as $(j) z(j) w$ «time, period» (Osing 1976b, I, 113; II, 588, Anm. 512). Existence of the word $z w$ «day of month» in the Old Kingdom is actually doubtful (cf. Edel 1955-1964, 182, § 420; Hannig 2003, 1079-1080; 2006, 2118-2120); in this regard, hereinafter I propose for the ideogram «calendar day» conditional reading $h r w$ rather than $s w$ which became almost generally accepted.

${ }^{43}$ Junker 1947, 31, Abb. 8, Taf. 6b; Abu Bakr, Osing 1973, 131.

${ }^{44}$ Osing 1976a, 154-155, Taf. 52.

45 Third inscription (Urk. I 1932-1933, 111; between Aswan and Philae) does not include any date.

${ }^{46}$ Kaiser et al. 1976, 79; Seidlmayer 2005, 290-291, Anm. 11, Taf. 6b. Rock niche of the temple of Satet on Elephantine Island. The name of king $n f r-k 3-r^{\ulcorner}$without indication of the regnal year is also attested herein.

${ }^{47}$ Urk. I 1932-1933, 110.10-16. Island of Hesse, the First Cataract of the Nile.

${ }^{48}$ Inscription Hatnub VI (Anthes 1928, 14, Taf. 5 = Urk. I 1932-1933, 256.18) also dates to the year after the $5^{\text {th }}$ occasion of the counting $\left(10^{\text {th }} / 11^{\text {th }}\right.$ regnal year $)$ of $m r j . n-r^{r}$.

${ }^{49}$ Osing 1976a, 160-164.

${ }^{50}$ Osing 1976a, 158-159, 164. 
as a special group since they were clarified by the title $n h s j$ «Nubian» ${ }^{51}$, though not always. Some persons were of the mixed descent ${ }^{52}$ which attests to the long-term contacts between Egyptians and Nubians. This impressive union of Nubians and Egyptians was in vassal dependence on Egypt for a long period of time, however for unknown reasons they rose in rebellion at the end of the reign of $m r j . n-r^{r}$. Egyptian $j w w-n m t j$ probably was a member of the expeditionary contingent in Nubia that became involved in the native rebellion and paid for that.

This list of holders of the name $j w w-n m t j$ should be supplemented with the data collected by Michelle Thirion ${ }^{53}$ :

2.5. $j w w-n m t j$. A gift bearer with the title $s m r$ «courtier» ${ }^{54}$.

2.6. $\wedge j w w-n m t j$. Statue Liverpool, World Museum, $1967.4^{55}$. He held the office of $j m j-r 3$ st hntjww-š pr- 3 «overseer of the bureau of the palace attendants» and was the son

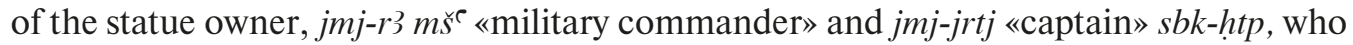
also held the ritual title $j m 3 h w w r n m t j ~ «$ revered with $n m t j{ }^{56}$. According to this title, both of them were natives of the $18^{\text {th }}$ (Sharuna - el-Kom el-Ahmar/Sawaris) ${ }^{57}, 12^{\text {th }}$ (Deir elGebrawi - El-Atawla) or $10^{\text {th }}$ nomes of Upper Egypt where the cult of the god $n m t j$ was practiced. Another son of $s b k-h t p$, also named sbk-htp, was jm3hhw hr st-jrt nb $\underline{d} d w$ jnpw $n b s p 3 n m t j n b t b t$ «revered with Osiris lord of Busiris, Anubis lord of Sepa, and Nemty lord of Qau». If my reading of the settlement name as in mind the cut off clows of the god $n m t j$ ) is correct, then it is the first occurrence of the name of the city Antaeopolis $(t b w)$, and it is about that the god $n m t j$ which cult localized in the $10^{\text {th }}$ nome of Upper Egypt.

2.7. $\wedge j w(w)-n m t j-w r\{t\}^{58}$. This masculine name is sometimes read as $j w t-n m t j$ or $n m t j-j w t^{59}$, however, judging from the photograph, it should be exactly read as $j w(w)$ $n m t j-w r\{t\}$, i.e. $j w(w)$-nmtj Elder (with the false feminization of the epithet $w r$ «Elder»

${ }^{51}$ Osing 1976a, 159-160. Remarkable example: leader («foreign ruler», $\left.h k 3-h 3 s t\right)$ of all rebels had the Egyptian name 'nh-wnjs «wnjs will live»; his Nubian name was j3tr3s (Abu Bakr, Osing 1973, 112-113 [199], Taf. 52-53).

52 This fact is established by the filiation data: Osing $1976 \mathrm{a}, 160$.

53 Thirion 2003, 178.

${ }^{54}$ Labrousse, Lauer, Leclant 1977, 108-109, fig. 99, doc. 73. Dating: wnjs.

${ }^{55}$ Reference data: PM VIII.1 1999, 280 (801-221-420); www.liverpoolmuseums.org.uk/ artifact/statue-of-sobekhotep (unsatisfactory photographs). Ihnasiya el-Medina. Dating: late Old Kingdom - beginning of the First Intermediate Period.

${ }^{56}$ Jones 2000, 25 (116), 28-29 (132-134); a Middle Kingdom ritual title jm3 $3 \mathrm{hw}$ hr nmtj nb 3tft «revered with $n m t j-$ lord of the $12^{\text {th }}$ nome of Upper Egypt» is also known (Fischer 1974, 19 (fig. 21), 21-22 (fig. 29), 25-26 (fig. 24)). About the god nmtj $n b 3 t f t ~ « n m t j-l o r d ~ o f ~ t h e ~ 12^{\text {th }}$ nome of Upper Egypt» on private monuments up to the $18^{\text {th }}$ Dynasty see also Abdel-Raziq 2017, 3-8, fig. 1-2.

${ }^{57}$ About the title $j m 3 h w$ hr $n m t j$ «revered with $n m t j »$ for noblemen of the $18^{\text {th }}$ nome of Upper Egypt in the Old Kingdom see Müller, Schenkel, Gomaà 2004, I, 114, 130, 145, 173, 193; II, Taf. 56-57, 77, 91-92, 130, 167.

${ }^{58}$ Cairo CG 20440 (Lange, Schäfer 1902b, Taf. 31; 1908, 38). Abydos. Dating: late $13^{\text {th }}$ Dynasty. The major part of the inscriptions on the stela were made in hieratic script.

${ }^{59}$ Thirion 2003, 178; cf. Ranke 1935, 69.17. 
because of a mistake made when transferring the hieratic text into stone ${ }^{60}$ ). This person is shown in the bottom register of the stela: his name was chiseled while several columns of the text, preceding it, were written in ink - nowadays, these inscriptions are completely lost. Name and title of the owner of the stela are written on the top in a mixture of hieratic and ideographic script, and the ideographic inscription on the arch of the stela changes the writing direction and the order of signs several times. The owner held the office of $j m j-r 3 z 3 n h r t j w$-ntr «overseer of a phyle of the craftsmen of the necropolis», and his name is probably also to be read $j w(w)-n m t j-w r$. If this is so, then the owner was depicted on the stela two times. The boy with the title $z 3=s$ «her son», standing behind the mother, also bears the name in honor of the god nmtj: nmtj-nht. Such propensity of the family for the cult of the god $n m t j$ makes it possible to assume that it originated from the $13^{\text {th }}$ or $18^{\text {th }}$ nome of Upper Egypt.

Several other names should be added to these data:

2.8. $s$ jww-nmtj. Graffito in Gebel Abrak (Eastern Desert) ${ }^{61}$. Title: jmj-r3 10 srjw smntjw «overseer of the ten prospectors and guides» ${ }^{62}$.

2.9.1. $\int_{j} j(w)-n m t j^{63}$. A servant of $j 3 m$, the owner of the stela. O.D. Berlev revealed three cases of scriptiones plenae of the divine name $n m t j$ in anthroponyms on this stela: $n m t j$ ${ }{ }_{n} h(=f)$ fem. (twice) and $n m t j-{ }^{\ulcorner} n h=f$ masc $^{64}$., however the name $j w(w)-n m t j$ with the same scriptio plena Berlev read simply as $n m t j$, although the sign «legs» $\wedge$ in it is obvious:

2.9.2-3. The name $j w(w)-n m t j$ in the similar form $\stackrel{\wedge}{\wedge}$ was also attested on stelae Cairo CG 20520 (masc.) ${ }^{65}$ and Rio de Janeiro, Museu Nacional, 627 [2419] (fem.) ${ }^{66}$. This name was included in Ranke's Personennamen as an alternative to the simple name $n m t j$ in scriptio plena ${ }^{67}$. The name $n m t j$ without the 'falcon on a boat' ideogram on the other stelae should also be understood as the divine name $n m t j$ adopted as the personal

${ }^{60} \mathrm{Cf}$. reading of this name as $N m t j-j w j j n \underline{d} s\{t\} \ll N m t j-j w j j$ Junior» in Abu Bakr, Osing 1973, 107, Anm. 26-27. About writing $n \underline{d} s$ «junior» with redundant $t$ (and reading $n \underline{d} s\{t\}$ ) compare example of the masculine name $j t j=s n-n \underline{d} s\{t\}$ (Moussa 1972, 290, Taf. 29). However, in this case the epithet $w r$ «Elder» was used rather than $n \underline{d} s$ «Junior».

${ }^{61}$ de Bruyn 1958, 97-98, pl. 14 (1).

${ }^{62}$ Reading $z \breve{s}$ «scribe» instead of the numeral $m \underline{d} w$ (10) is implausible (cf. de Bruyn 1958, 97; Eichler 1993, 91 (188); Jones 2000, 218 (814)) since the title $j m j-r 3$ z žw «overseer of scribes» is not used without specifying the name of the department. For the reading see also Fischer 1985, 31, n. 24.

${ }^{63}$ Stela Lyon, Le Musée des Beaux-Arts 1969-134 (PM VIII.3 2007, 204 (803-030-370)); formerly Guimet C13: Moret 1909, 29-31, pl. 12 (13); collections.mba-lyon.fr/fr/searchnotice/detail/1969-134-stele - b4398http://www.bubastis.be/art/musee/lyon/lyon_086a.html). Many members of this family are also depicted on stela Leiden, Rijksmuseum van Oudheden, CI.325 (or Leiden V 111: PM VIII.3 2007, 166 (803-030-039); Boeser 1909, 7 [21], Taf. 20). Dating: early $12^{\text {th }}$ Dynasty.

${ }^{64}$ Berlev 1969, 18-20.

${ }^{65}$ PMV 1937, 73; Lange, Schäfer 1902b, Taf. 36; 1908, 121; Simpson 1974, pl. 50 (ANOC32.1). Abydos.

${ }^{66}$ PM VIII.3 2007, 86 (803-026-718); Kitchen 1990, I, 16-17; II, pl. 1-2 (1), with a mistake in the transcription of the name. Abydos.

${ }^{67}$ Ranke 1935, 204.13-15, with references to Cairo CG 20077, 20098, 20520, 20591, 20605; to be added: Abydos field no. ANC11543: T/ (Adams 2010, 5-7, fig. 4-5). 
name ${ }^{68}$ considering to the parallels on the other stelae or to the names of the relatives (for example, the name $n m t j-h t p$ on stela Cairo CG $20605^{69}, n m t j-w r$ on stela Cairo CG $20520^{70}$, Antaeopolite names on stela Cairo CG 20591 ${ }^{71}$ ). This is why the sign «legs» $\wedge$ could also not be the determinative for the hypothetic name $n m t j$ «wanderer» from the verb $n m t$ «walk, wander»: the name $n m t j$ always meant only the god-wanderer. Although, on rare occasions, the divine name $n m t j$ is presented only by the ideogram «legs» with the phonetic complements $(\hat{\sim})^{72}$, the sign $\widehat{\wedge}$ after the ideogram of the falcon-god on a boat was not reliably attested. In this regard, I distinguish the name $₫ \wedge \wedge$ from the simple name $n m t j$ in scriptio plena and read it as $j w(w)$-nmtj despite the fact that the element $j w(w)$ is presented in it as a single sign "legs", i.e. in the form which does not occur in the full variants of the name $j w(w)-n m t j$.

2.10. .

Spelling the name in inscriptions Abrak (2.8) and Sinai 85 (2.10) is of interest. In the first case the writer violated the rule of pronouncing the divine name honoris causa, in the second case the component $j w w$ is presented in the full form. Thus, it is necessary to read the name as $j w w-n m t j$ «coming of $n m t j »$ where $j w w$ is nomen actionis from the verb $j w j$ «come». The word $j w w$ «coming» ${ }^{74}$ means the child himself who impersonated «appearance» (of a certain god) before the father.

The reading of the name as $j w w-n m t j$ is confirmed by several examples of the names from the Old and the Middle Kingdoms that were formed on the similar principle - with the initial nomen actionis from the verb $j w j$ «come». This pattern coexisted with the similar derivatives in the form $s \underline{d} m=f$ or with a pseudo-participle from the verb $j w j$. The following examples of the names with nomen actionis $j w w / j w t$ «coming» can be found in the anthroponymy of the Old and the Middle Kingdoms:

${ }^{68}$ The name $n m t j$ with the ideogram of falcon on a boat occurs frequently: Ranke 1935, 69.16. The tradition of giving to a child the name of a deity ( $\underline{d} h w t j, h r, n m t j, h w t-h r$, etc.) without any epithet appeared in the Middle Kingdom. The Old Kingdom names hnsw (fem.) and $h n m w=j /$ $\underline{h} n m t=j$ are not related to the gods $h n z w$ and $h n m w$ respectively (another reading: ScheeleSchweitzer 2014, 603 [2783], 615-616 [2861]-[2863]).

${ }^{69}$ Lange, Schäfer 1902b, Taf. 48; 1908, 243-244. Abydos.

${ }^{70} j m j-r 3$ pr «householder» nmtj-wr (fis ) on stela Cairo CG 20520 and jmj-r3 pr «householder» $n m t j$-wr (s) on stela Leiden, Rijksmuseum van Oudheden, L.XI.2 (Leiden V 108: Boeser 1909, 13 [50], Taf. 38; Simpson 1974, pl. 16 (ANOC7.2) are apparently the same person (Franke 1984, 217 (325)).

${ }^{71}$ PM V 1937, 58; Lange, Schäfer 1908, 230. Abydos; about ancestry of some members of this family from the $10^{\text {th }}$ nome of Upper Egypt see Ilin-Tomich 2017, 84, 211.

${ }^{72}$ Indisputable examples from the Coffin texts: Graefe 1980, 9.

${ }^{73}$ Gardiner, Peet, Černý 1952, pl. 23; Černý 1955, 92-94. Dating: 4th regnal year of king [jmn-m-ḩ3t III]. Serabit el-Khadim.

${ }^{74}$ About «coming (of the god)»: Hannig 2006, 100. For example, appearance of the god Sobek signifies the renaissance in the shrines of the gods - inhabitants of the Underworld (jmjw$d w 3 t)$ and inhabitants of waves (jmjw-nwj): h`j sbk whm.n=f mswt $m$ jww $=f j p$ frrw «when Sobek appears, he revives by his coming (everyone) in particular and in general» (pRamesseum VI (BM EA 10759), col. 116-117: Gardiner 1957, 53, pl. 3; cf. Vernus 1980, 118; Assmann 1999, 462. Dating: jmn-m-h3t III). In this text, the terms jp / nfrw are a combination of opposites with the meaning "particular / general" or "special / common". 
1. 政 $\wedge j w w-b 3$ 《coming of the sacred Ram» ${ }^{75}$. Double waw indicates the form nomen actionis from the verb $j w j$ «come».

2. jww-bnw «coming of phoenix». Two individuals are known who have that name attested in the different spelling: 1) $\int_{0} \wedge 76$ and 2) $10 \wedge 77$.

3. 1 s jww-pth. This name in the form nomen actionis is mentioned on a stela of the First Intermediate Period ${ }^{78}$. A similar name, but in a different form, is attested in the Second Intermediate Period: $\wedge$ pth-jw.j where $j w . j$ is a pseudo-participle ${ }^{79}$.

4. (in the feminine gender) was formed according to another model of nomen actionis ${ }^{81}$.

5. $\approx j w(w)-n=j$-sbk «coming of Sobek to me» ${ }^{82}$ where the word $j w w$ «coming» is nomen actionis with the $w$-ending as in the name jww-nmtj ${ }^{83}$. Nqmen 'stiqnis is used in

${ }^{75}$ Cf. Scheele-Schweitzer 2014, 222 [172]: $J w(j) . w-B 3$ «kommend ist der (heilige) Bock»; Gundacker 2013, 45: Jwjw-Bt «Bata soll kommen!»; Gundacker 2014, 67: Jwjw-B3 «Der heilige Bock soll kommen!».

${ }^{76}$ Stela BM EA 1486 [1136] (Budge 1912, pl. 52; Fischer 1987-1988, 19-20, 23, fig. 3. Dating: $9^{\text {th }} / 10^{\text {th }}$ Dynasty.

77 Stela Berlin, Ägyptisches Museum 14333 (Generalverwaltung 1913, 121. Dating: $9^{\text {th }} / 10^{\text {th }}$ Dynasty. Both stelae probably originate from El-Qasr wa's Sayyad necropolis (Brovarski 2018, 361, n. 83). For reading the name cf. Ranke 1935, 97.10; 1952, 277.10; Schindler von Wallenstern 2011, 231.

${ }^{78}$ Stela Firenze, Museo Archeologico Nazionale, 6367 (1760) (Bosticco 1959, 22, fig. 15 (15); Fischer 1964, 80-81, pl. 24 (27). Naqada). Cf. Ranke 1935, 138.12.

${ }^{79}$ Stela BM EA 329 [1371] (Budge 1913, 7, pl. 16; Vernus 1987, 146-149, pl. 26 (46). Edfu). Cf. stela Aix-en-Provence, Musée Granet, 849.1.367 (PM VIII.1 1999, 91: (803-027-141); Barbotin 2020, 56-59 (7). Abydos (?)) where the name of the same pattern but with a different spelling is attested: 매요 with the reading $p t h-j w . j$.

${ }^{80}$ Cf. Ranke 1952, 358 [138,13]; Scheele-Schweitzer 2014, 222 [176]; Gundacker 2013, 45; Gundacker 2014, 67: everyone is reading and understanding this name in the same way: $j w t$ $n=j$-pth «möge Ptah zu mir kommen».

${ }^{81}$ Tomb LG 77 (PM III.1 1974, 212; Lepsius 1849-1859, II, Bl. 34d; Urk. I 1932-1933, 8.14; www.gizapyramids.org: A7429_NS; Kormysheva et al. 2015, 25, fig. 15, pl. 2, 14a-b. Giza East Field. Dating: $5^{\text {th }}$ Dynasty). Cf. the name in $s \underline{d} m=f$ form, with the same meaning: $p t h-j w(j)=f-n=j$ «Ptah, he came to me» (Scheele-Schweitzer 2014, 362 [1146]).

${ }^{82}$ Relief Krannert Art Museum, University of Illinois, Champage-Urbana 1974-11-1; collection.kam.illinois.edu/Obj3799. Dating: ppj II.

${ }^{83} \mathrm{Cf}$. reading in Gundacker 2010, 70; Gundacker 2013, 44; Gundacker 2014, 67: $(J) m j-n=j-$ Śbkw «Komm zu mir, Sobek!» (m.). I interpret the grammatical form of the similar examples given in Gundacker 2010, 70: Ex. (53, $\left.d w 3-n=j-R^{\top} w\right)$, Ex. (54, $\left.h s j-n=j-P t h\right)$, and Ex. $(55, j 3 j-n=j-$ $P t h)$ ) as the perfective relative form. It is difficult to translate these names, though the common content is approximately like the following: $d w 3 . n-r^{\ulcorner}$«the one who (came) by the grace of Ra» («begged for from the Sun»), hzj.n-r` «the one who (came) by the grace of Ra» («blessed by the Sun»; it is worth noting that the verb $h z j$ «favor, praise, reward» always expresses action of a lord with respect to a subordinate or a father to his son, and not vice versa) and j3j.n-pth «the one who came through prayer to Ptah» («begged for from Ptah»). Analogues of these names with a participium perfecti passivi (i.e. without $n$ ) and with the same meaning are also known: $d w 3-r^{\complement}$ (cf. Scheele-Schweitzer 2014, 743 [3770]: «der Re preist»), hzj-r` (cf. Scheele-Schweitzer 2014, 554 [2510]: «Gelobter des Re»), j3jw-pth (cf. Scheele-Schweitzer 2014, 207 [61]: «Verehrer des Ptah»). 
the $n^{`}$ mes $N q .4$ 'nd 5 inste' $d$ qf the simple $s \underline{d m}=f$ form (as in the name pattern $j j-n=j-\mathrm{NN}$ «NN came to me» $\left.{ }^{84}\right)$.

6. «good coming» which his father also held ${ }^{85}$. The variant $n f r-j w w$ with the epithet $n f r$ «good» confirms the meaning of the word $j w w$ «coming» as nomen actionis once more. The Middle Kingdom names of this type with the element $n f r$ were divided into two patterns: $n f r$-jww ${ }^{86}$ $\left\lceil n d j w w-n f r\right.$ «good coming» ${ }^{87}$, to which adjoined the name jww-nfrt «coming of the beauty» ${ }^{88}$. The name $j w w-n f r / n f r-j w w$ occurs dozens of times in the Middle Kingdom, both for men and women. On the contrary, the equally widespread name jww-nfrt occurs only for women and only in the Middle Kingdom. Its Old Kingdom prototype $n f r t-j w w=s$ «beauty, (this is) her coming» ${ }^{89}$ gives more reason to see the goddess Hathor in this «beauty». This explains the constant carrying forward the word $n f r t$ «beauty» in the Middle Kingdom name $j w w-n f r t$ whereas position of the verb $n f r$ «be good» in the name $j w w-n f r / n f r-j w w$ is not stable; thus, the name patterns of $j w w-n f r / n f r-j w w$ (masc./fem.) and $j w w-n f r t$ (only fem.) are not equivalent. The name pattern with pseudo-participle $n f r t-j j . t j$ «the beauty is coming» (Nefertiti) on the Middle Kingdom material is not attested. In this name, as before, Hathor is the deity who is hiding under the name $n f r t ~ « b e a u t y »{ }^{90}$, which appeared during the $18^{\text {th }}$ Dynasty and survived into the Ptolemaic period (also in the form $t 3-n f r(t)-j j . t j$ ).

7. $n f r-j w w-h w t-h r$ «coming of Hathor is good» ${ }^{91}$. The female name in which $j w w$ «coming» can be understood only as nomen actionis.

A compound name $j m n-m-h 3 t-n f r-j w(w)^{92}$ is also known, however in this case $n f r-j w(w)$ is only the second name of the man ${ }^{93}$.

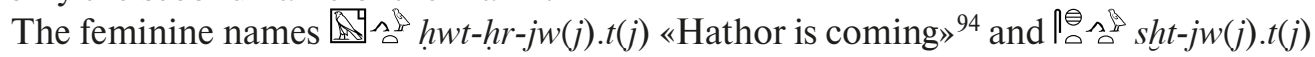
«Sekhet (Field-goddess) is coming» ${ }^{95}$ should be considered as pseudo-participial constructions, built according to a name pattern with the masculine subject $k 3=j-j w(j . j) / k 3=j$ $j w(j) . w$ «my $K a$ is coming», with the element $k 3$ in the initial position ${ }^{96}$. Generally, the

\footnotetext{
${ }^{84}$ Scheele-Schweitzer 2014, 212-213 [97]-[103].

${ }^{85}$ Stela Cairo CG 20142 (Lange, Schäfer 1902a, 167-168; 1902b, Taf. 13). Abydos. Dating: $13^{\text {th }}$ Dynasty.
}

${ }^{86}$ Ranke 1935, 194.7-8. There are two examples from the Old Kingdom: Scheele-Schweitzer 2014, 462 [1839].

${ }^{87}$ Ranke 1935, 15.21, 194.7.

${ }^{88}$ Ranke 1935, 201.13-14.

${ }^{89}$ Scheele-Schweitzer 2014, 490 [2038].

${ }^{90}$ Ranke 1935, 201.12, 364.2; cf. ibidem, 194.5.

${ }^{91}$ Scheele-Schweitzer 2014, 462 [1840], with reading Nfr-jww-hw.t-hr.w(?) «gut ist, daß Hathor kommt»; Gundacker 2014, 96, Ex. (109): «Vollkommen ist, daß Hathor kommt!».

${ }^{92}$ Stela Coll. Figeac (Marseille): Gauthier-Laurent 1933, 75-80, pl. 7.

${ }^{93}$ Vernus 1971, 196 (13); Vernus 1986, 8 (19).

${ }^{94}$ Tomb QH 90. Edel 2008, II, 1135-1136, Text 6; Taf. 63. cf. Scheele-Schweitzer 2014, 222 [177]: $J w . t-h w . t-h r . w$ «möge Hathor kommen».

${ }^{95}$ El-Hagarsa D4. Woodward, Kanawati 1995, pl. 5a, 24, 27; cf. Scheele-Schweitzer 2014, 222 [178]; Gundacker 2013, 45; 2014, 67: Jw.t-sh.t «möge Sechet kommen».

${ }^{96}$ Scheele-Schweitzer 2014, 693 [3423]. The form $k 3=j-j w(j) . w$ is an example of existence of the pseudo-participial ending. $w$ for the verb jj/jwj «come» already in Old Egyptian (cf. Edel $1955-1964,272, \S 573 ; 278, \S 579$ ), which further demonstrates the diatopic character of 
sign «legs» in the name $h w t-h r-j j . t j / ~ h w t-h r-j w(j) . t j^{97} w^{\top} s m^{\top} d e$ purpqsely mqre sqmplis`ted tq the sign $j j(\AA)$, since in the name form $j w w / j w t$ «coming» this sign was never used, only the sign $j w(\Omega)$; on the contrary, this simple sign $j w(\Omega)$ was sometimes used to form a pseudo-participle - for example, the name $h w t-h r-j w(j) . t j$ «Hathor is coming» on stela Louvre $\mathrm{C} 111^{98}$ is presented in the full writing: $\wedge$. Thus, the pseudo-participle from the verb $j w j$ in this name is presented in two forms: $j j . t j$ and $j w(j) . t j$ «she is coming» which also occurs in other names.

Taking into account the anthroponymic material, military officers, expedition members and travelers often held the name $j w w-n m t j$ which indicated that they followed footsteps of their fathers who served in the same professional sphere. A separate group is made up of those born in the $10^{\text {th }}, 12^{\text {th }}$ or $18^{\text {th }}$ nomes of Upper Egypt (Nos. 2.6, 2.7, 2.9.1-2, 3(?)) who got their names with the component nmtj out of reverence for the local god of their nomes, the Falcon on a boat.

3. Author of the inscription on the offering basin, son of $j w w-n m t j$, had the name $n j-$ $k 3=j-r^{c}$ «my Ka belongs to Ra».

This name was fairly common in the Old Kingdom. Scheele-Schweitzer's Handbuch provides data about eight bearers of this name ${ }^{99}$. Besides them, the following persons are known:

3.1. špsj nswt jmj-r\} $k d w$ «king's nobleman, overseer of builders» $n j-k 3=j-r^{c}$, father of $j m 3 h(w) t$ «revered» $t \underline{t} j^{100}$. his sqrrespqndenśe tq shd $k d w$, sh $\underline{d} \underline{h} m w-k 3$ «inspector of builders,

divergence between the pseudo-participial forms, with the endings. $j$ and. $w$, as well without any ending in Egyptian language. Cf. the names $j j-k 3=j \ll$ my $K a$ came» and $j j-k 3 w=j \ll$ my Kau came» in the form $s \underline{d m}=f$ (Scheele-Schweitzer 2014, 216-217 [124]-[126]).

${ }^{97}$ Ranke 1935, 235.7-8 (with reference to stelae Cairo CG 20076 and CG 20473; Louvre C111; Wien ÄS108). To add: 1) stela Louvre E27211 (Ziegler 1990, 74-77 (8); 2) inscription Kumma 452 = Khartoum, Sudan National Museum 34381 (Hintze, Reineke 1989, I, 127; II, Taf. 172); 3) stela Langres 110 (Gauthier-Laurent 1931, 110-111, pl. 1); 4) statue Dahshur Magazine 160 (Fakhry 1961, 20, fig. 295, pl. 57A; Schulz 1992, I, 128-129 (053); II, Taf. 22c); 5) stela Moscow, The Pushkin State Museum of Fine Arts I.1.a.1136 (Hodjash, Berlev 1982, 86-87 (40)); 6) stela Cairo CG 20656 (Lange, Schäfer 1902b, Taf. 50; 1908, 289; Stefanović 2011, 98, 100); 7) stela Cairo CG 20228 (Lange, Schäfer 1902a, 248; 1902b, Taf. 17). All the examples date to the Middle Kingdom and the Second Intermediate Period.

${ }^{98}$ https://collections.louvre.fr/en/ark:/53355/c1010022897. Dating: $13^{\text {th }}$ Dynasty. The owner of the stela $k k j$ held a rare title $j r j-h t m(j) t$ «he who is in charge of the sealed property» (Hannig 2006, 346 ) which existed within the community of low-rank court administration from the end of the $5^{\text {th }}$ and during the $6^{\text {th }}$ Dynasties (Jones 2000, 334 (1231); Hannig 2003, 179-180; Bogdanov 2017b, 166-167; the title is also attested on the false door of sbk-htp in tomb G 2420 (www.gizapyramids. org: A7580_NS. A7588_NS); on the sealings $\underline{d} d-k 3-r^{r} 27$ and 30 (Kaplony 1981, IIA, 330-331, 333-334; IIB, Taf. 89-90), and on the false door of $k d w$ (Cairo CG $57196=$ SR2/15892; Kamal El-din 2009, 19-26. Saqqara (?). Dating: $8^{\text {th }}-9^{\text {th }}$ Dynasties. This person, who held the office of

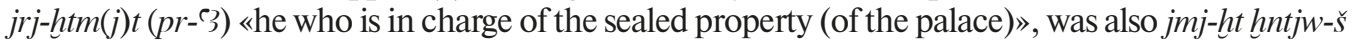

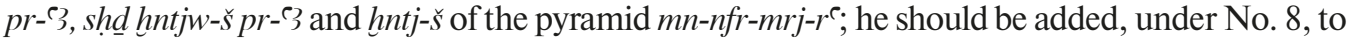

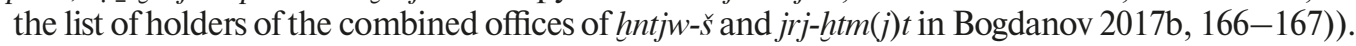
In the narrative context, the title jrj-htmt «contract holder (?)» is attested in the inscription on the statue base of $h r-j r-\Im$, line 13 (Perdu 2016, 92-93, 115, n. ao), pl. 10. Dating: psmtk II $\left.n f r-j b-r{ }^{\top}\right)$.

${ }^{99}$ Scheele-Schweitzer 2014, 443 [1698].

${ }^{100}$ Offering basin from tomb G 6027 A (www.gizapyramids.org, Field number: 38-2-13). 
inspector of funerary priests» $n j-k 3=j-r^{r}$, a servant of $j j-m r j$, owner of tomb G $6020^{101}$, remains questionable since presence of the title $\breve{s p} s j n s w t$ «king's nobleman» for $n j-k j=j-r^{c}$ on the offering basin is a clear evidence in favour of dating to at least the reign of $t t j$ while usually tomb G 6020 (jj-mrj) is reasonably dated to at least the first half of the $5^{\text {th }}$ Dynasty.

3.2. $n j-k 3=j-r^{r}$, son of $h\left\ulcorner j-m r r-n b t j\right.$, grandson of $h w f w-s n b$ and $h n w t=s n^{102}$.

\section{Commentary on the titles}

Two titles from the sphere of the organization of expeditions are attested on the offering basin:

1. $n j-k 3=j-r^{r}: j m j-h t$ srjw «under-supervisor of prospectors».

2. $n j-{ }^{\ulcorner} n h=j-n m t j$ / jww-nmtj: sh $\underline{d}$ srjw «inspector of prospectors».

Range of problems connected with interpretation of the lexical item $s r j$ «presage, forecast, predict» etc. ${ }^{103}$ Social designations from the sphere of lexicography of srj deserve a separate study; this is why for the present I limit myself to categorical conclusions on the initial results of my own study which hopefully shall be completed soon.

Considering the meaning of the word $s r(j)$ «official, office-holder» ${ }^{104}$, many scholars interpreted the term $s r(j) w$ in the expedition titles as «officials» ${ }^{105}$. However, it should be noted that actually the office $s r(j)$ «official» did not existed in the Old Kingdom. The term $s r(j)$ in Old Egyptian was used in the meaning derived from the verb «envisage», however with many nuances depending on occupation of the holder: «auditor, controller, agent, informer, scout». In most of the narrative contexts (i.e. outside the titulary) it appeared as a general notion $s r(j)$ «official» with the non-determined content. The title $s r(j)$ transformed into a functional office only in the expedition nomenclature where to it was included with the meaning «geological explorer, prospector». It occurs mostly in the hierarchical titles $j m j-r\} s r(j) w / s h d s r(j) w$ «overseer / inspector of prospectors».

The contingents of srjw often appear in the titles together with the crew of smntjw which is indicative of resemblance of their functions. And because smntjw are usually determined as «guides» ${ }^{106}$, then for the title srjw a suitable equivalent is «prospectors»; it is derived from the verb $s r(j)$ in the meaning «survey the routes, plot the sailing directions» which were widely used, in particular, in the Coffin Texts. Units of «prospectors»$s r j w$ were generally a part of the expeditionary force in the quarries of the Sinai, Wadi Hammamat, Hatnub, Nubia and other remote locations. Nevertheless, according to the titles of their superiors, srjw could serve in the Nile valley as well. Functions of such $s r j w$ in Egypt itself, probably, were to accompany goods and to send reports along the

${ }^{101}$ Weeks 1994, 51, fig. $42\{2.120\}$.

${ }^{102}$ www.gizapyramids.org: PDM_06135; PDM_06142; Giza Abu Bakr Cemetery. Dating: $5^{\text {th }}$ Dynasty.

${ }^{103}$ Cannuyer 2010, passim.

${ }^{104}$ Wb. IV, 188.3-189.9; Jones 2000, 909 (3331); Cannuyer 2010, 577-579.

105 Goelet 1982, 200-201 (n. 199); Fischer 1985, 31; Eichler 1993, 169; Martin-Pardey 1994, 159-160, 162; Moreno García 1997, 108; Jones 2000, 229-230 (849-851), 909 (3331-3335), 966-967 (3564-3565), et al.

${ }^{106}$ The title-nisba smntj is apparently derived from the word smnt «knapsack, bag» $(\mathrm{Wb}$. IV, 135.18; Yoyotte 1975, 44-55; Jones 2000, 228-230 (846-851), 872 (3191); 891 (3262), 966 (3563); Mostafa 2014, 156, fig. 21, 158, 165, n. g, 166, n. b). 
routes that were plotted by them, while outside of the Nile valley they were conducting the prospecting. The ordinary srjw and smntjw, along with different categories of soldiers and craftsmen, had a very modest status, so there are almost no inscriptions of them ${ }^{107}$.

\section{The title jmj-ht srjw «under-supervisor of prospectors».}

I chose for the rank jmj-ht (literally meaning «one who follows, one who goes after») the conditional translation «under-supervisor» ${ }^{108}$. This rank was the second in the phyle of employees directly after «inspector» sh $\underline{d}$. In the Middle Kingdom the hierarchic rank $j m j-h t$ disappeared from almost all government bodies, apart from the police: it remained only as part of the title jmj-ht z3w-prw «under-supervisor of policemen (or gendarmes, literally «sons of the house(s)»)» ${ }^{109}$.

The title $j m j$ - ht srjw «under-supervisor of prospectors» held by the author of the inscription, $n j-k\}=j-r^{c}$, is unique. The only parallel to it from the sphere of organization of the expeditions, is the office of $j m j$ - ht smntjw «under-supervisor of guides» which occurs very rarely as well:

1. In graffito of $h t p w$ in the form $j m j$-ht smntjw $m r r n b=f$ «under-supervisor of guides beloved of his lord» ${ }^{110}$.

2. On a sealing with the name of king $[h r] w s r-h^{\varsigma} w$ from Buhen ${ }^{111}$.

3. On a sealing with the name of king $h r \underline{d} d-h^{\complement} w, \underline{d} d-k^{3}-r^{\top}$ from Edfu in the form [jmj]ht smntjw jrr wdt $n b=f$ «under-supervisor of guides who does what his lord commands» ${ }^{12}$.

The unique title in Wadi Hammamat, published in transcription as jmj-ht $m s^{\longleftarrow}$ «undersupervisor of army» ${ }^{113}$, should most likely be read as jmj-ht smntjw «under-supervisor of guides".

The only known namesake of $n j-k 3=j-r^{\complement}$ served in the administration of the contingent of $s r j w$ is $w r m d \underline{d} \breve{s}^{c} w z \check{s}$ «great (among) the tens of Upper Egypt, scribe» ${ }^{114} n j-k 3=j-r^{c}$. He

${ }^{107}$ Data about the single title smntj of Middle Kingdom, presented in Rainer Hannig's dictionary, are either incorrect (for example, on stela Cairo CG 20457 it is the personal name mnjw, cf. Fischer 1996a, 177) or doubtful (for example, on stela «cCassirer» (Schlögl 1978, 49, 155; cf. Meeks 1998, II, 327, 78.3547) a title of musician is mentioned, most probably, it means «castanets or sistrum player» (srwj?/shmj?) rather than smntj), or represent the group spelling (Hannig 2006, 2212 $\{28076\})$. About the ordinary title srj: Tallet 2012a, I, 218-219, II, 154 (CCIS247).

108 Jones 2000, 282-298 (1017-1090); Hannig 2003, 130-132.

${ }^{109}$ Jones 2000, 296 (1081): «under-supervisor of sons-of-houses (police)»; Hannig 2003, $132 ; 2006,240-241$.

${ }^{110}$ Wadi Hammamat M 156: Couyat, Montet 1912, 93, pl. 33; see also photographs of the inscriptions on the website ancienegypte.fr/ouadi_hammamat/page2.htm (45.jpg). To the reading of the inscription: Bogdanov 2018, 239, n. $\overline{7} 5$.

${ }^{111}$ Kaplony 1981, IIA, 227; IIB, Taf. 69 (nfr-ir-k3-r $\left.{ }^{\bullet} 28\right)$. See also fragments of the title $j m j-$ ht smntjw (?): Kaplony 1981, IIB, Taf. 16 ( $r^{\top}-h^{\top}-f$ 16); 46 (mn-k3w-r` 39); 64 (s3hw-r 44$) ; 132$ (K.u. 138); 133 (K.u. 139); about reading cf. IIA, 124-125, 204, 500.

112 Moeller, Marouard 2020, 16.

${ }^{113}$ Wadi Hammamat M 161: Couyat, Montet 1912, 93 (without photograph); cf. Jones 2000, 287-288 (1044).

${ }^{114}$ Another reading of the title: Jones 2000, 845-846 (3085) (žs wr(w) $\left.10 \breve{s} m^{\complement} w\right)$. The element $z \check{s}$ «scribe» in this title should be considered as a functional addition to $w r m \underline{d} w \check{s} m^{\top} w$ «great (among) the tens of Upper Egypt». 
left behind many monuments ${ }^{115}$, and his titulary is exclusively rich with offices from different spheres of activity ${ }^{116}$. He was a priest $h m-n t r$ of kings [s $\left.h h\right] w-[r], h r$ [wsr-ḩ $] w$ (nfr$\left.j r j-k 3-r^{\top}\right), h r s t-j b-t 3 w j\left(n j-w s r-r^{\complement}\right)$ and $h m-n t r r r^{\ulcorner}$«priest of the Sun» in the Sun temples [st]$j b-\left[r^{\ulcorner}\right]$(of king $n f r-j r j-k 3-r^{\ulcorner}$) and $\check{s} z p(w)-j b-r^{\complement}$ (of king $n j-w s r-r^{\ulcorner}$). The main activity $n j-k j=j-r^{\complement}$ related to the ministry of food where he held several offices ${ }^{117}$ : [jmj-r3] $s n w t j$ «overseer of the (department of) two granaries», [jmj-r3] žš md ments for the (department of) granary», jmj-r 3 šnwt $n(j) t$ t $h n w$ «overseer of the (department

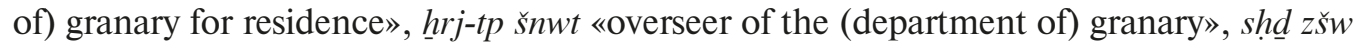
šnwt «inspector of scribes of the (department of) granary» ${ }^{118}$. The title jmj-r $r$ šnwt «overseer of the (department of) granary» was also held by his son ${ }^{\complement} n h-m-{ }^{-}-r^{\ulcorner} \cdot n j-k 3=j-r^{`}$ himself was also involved into organization of cattle breeding and hunting which is evidenced by such his titles as $j m j-r 3 h w t-{ }^{-} 3 t$ «overseer of the great estate», $j m j-r 3 h w t-j h w t$ «overseer of the estate for the cattle breeding (with the town determinative)», jmj-r $r 3 p d w-\check{s}$ «overseer of pond-fowl» ${ }^{119}$, jmj-r3 $p h w w n b$ «overseer of all marshlands», jmj-r3 $n w w n b$ «overseer of all hunters», jmj-r3 bjtjw $n b$ «overseer of all bee-keepers» ${ }^{120}$. Such unusual offices as $j m j-r 3$ ( $h r j w)-s b 3 n b$ «overseer of all parasol bearers» ${ }^{121}$ and jmj-r3 $m s w n s w t$ (prw) $m$ prwj «overseer of the (houses of) king's children in the two houses» can also be added into this group.

The title jmj-r3 srjw of the word $s r j$ by only the ideogram of the official without any phonetic complement is

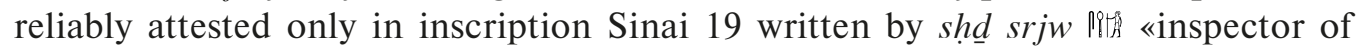

${ }^{115}$ PM III.2 1981, 696-697. The monuments of $n j-k 3=j-r^{r}$ include: $1-2$. Statue Cleveland Museum of Art 1964.90 and fragments of false door Cleveland Museum of Art 1964.91 (Andreu 1997, 21-30; Fischer 1997, 178-179; Hamza Awad 2006, 73-87; Berman, Bohač 1999, 128-132 (71-72); www.clevelandart.org/art/1964.91; www.clevelandart.org/art/1964.90); 3. Statue Brooklyn 49.215 (James 1974, 13 (36), pl. 19; www.brooklynmuseum.org/opencollection/objects/3544); 4-5. Statues New York, MMA 52.19 and 48.67 (www.metmuseum.org/art/collection/search/543900; www.metmuseum.org/art/collection/search/543901). Probably from Saqqara. Dating: $n j-w s r-r^{r}$.

${ }^{116}$ About titles of $n j-k 3=j-r^{`}$ see also Baud 1999, II, 481, no. 103 (V 6); Nuzzolo 2018, 360-361 [51]; Florès 2015, $417(\mathrm{Ni} / \mathrm{Sa} / 1)$.

${ }^{117}$ The Old Kingdom «overseers of the granary / two granaries» performed the functions of the agriculture ministers. This office was reliably attested from the beginning of the $5^{\text {th }}$ Dynasty (Strudwick 1985, 251-275).

118 The title $h r j-t p \breve{s} n w t$ «chief of the (department of) granary» is mentioned on statues Cleveland Museum of Art 1964.90, New York, MMA 52.19 and 48.67; the titles rh nswt «king's acquaintance» and $s h \underline{d} z \check{s} w \check{s} n w t$ «inspector of scribes of the (department of) granary» is attested only on statue Brooklyn 49.215.

${ }^{119}$ For the reading $3 p d w-m r / \breve{s}$ «channel-bird, pond-fowl» see Hayes 1951a, 53, fig. 13 (170-181); 1951b, 92-93; Wassell 1991, II, 27-28, n. 98; Bailleul-LeSuer 2016, 29, 341, 377-378, 381. Cf. Andreu 1997, 22; Fischer 1997, 178; Jones 2000, 52 (258); Diego Espinel 2006, 87; Hamza Awad 2006, 75, 80; Nuzzolo 2018, 360: everyone is reading the title as š̌(.w)?, or as $3 p d(w)$, or as $3 p d(w)-m r / s ̌$. Reading in Florès 2015, 417: «(j)m(y)-r(3) $s 3 m r ? »$.

${ }^{120}$ Reading in Hamza Awad 2006, 75, 78: «jmj-r3 [...] bjt $n b(. w)$ ?» is incorrect.

${ }^{121}$ Cf. readings in Hamza Awad 2006, 75, 78: «jmj-r\} $s b[. .] n b.(. w)$ ?»; Nuzzolo 2018, 360: «imy-r $s b(w)[\ldots] n b(w) »$; Florès 2015, 417: «(j)m(y)-r(3) $s b[\ldots ?] n b »$. About this title: Bogdanov, Bolshakov 2004, 23; this article was afterwards reprinted in English: Bolshakov 2005, 47, n. j).

122 Review of the readings of this title in the inscription: Hamza Awad 2006, 75, 83-84. 
prospectors» snnw jdw ${ }^{123}$. Nevertheless, the title jmj-r3 srjw on false door Cleveland 1964.91 apparently has nothing to do with the organization of expeditions. The titulary of $n j-k 3=j-r^{r}$ is in many respects similar to the titulary of $d m \underline{d}^{124} w h q$ ' lsq held the qffise qf srjw and also was jmj-r3 žs «overseer of the fowling pool» (the sense of the title is not known), $j m j-r 3 \breve{s} n j w-t 3 n b$ «overseer of all vegetation», jmj-r3 $p h w w$ «overseer of marshlands», jmj-r3 $w h^{\top} w$ «overseer of fowlers/fishermen» and a priest of the Sun (hm-ntr $\left.r^{r}\right)$ in the Sun temples $s h t\left(-r^{\ulcorner}\right)$(of king $\left.s 3 h w-r^{\top}\right)$ and $s t-j b-\left(r^{c}\right)$ (of king $\left.n f r-j r j-k 3-r^{\ulcorner}\right)^{125}$.

According to these indirect data, the office of jmj-r3 srjw held by $d m \underline{d}$ and $n j-k \beta=j-r^{c}$ was probably related to the management of auditors ${ }^{126}$ or guides ${ }^{127}$. Needless to say, that the bosses themselves did not participated in the trips - their status did not allow them. Here, as in the expedition inscriptions, the title srjw - in broad sense «informer, prospector, auditor, researcher» - has one meaning but different content. In Egypt srjw could play a role of attendants of the military or fiscal missions, and in expeditions the many professional miners and prospectors were called by the same title.

Thus, competence of two persons named $n j-k 3=j-r^{\top}$ with the resembling titles turns out to be ghost and their identity - unreliable.

\section{The title shd srjw «inspector of prospectors» ${ }^{128}$.}

Bearers of the title shd srjw can be divided into two categories: 1. The expedition members as inspectors of prospectors. 2. Officials of the fiscal service, «inspectors of auditors». The first ones left their inscriptions outside of Egypt, the others, with few exceptions, are known from the monuments from their own tombs in the Memphite region, at Giza and Saqqara. Since it is not easy to identify the functions of officials from the second group, I present their prosopography separately.

1. The expeditionary $s \underline{h} \underline{d} w$ srjw «inspectors of prospectors» left inscriptions in the Sinai, in Wadi Hammamat and Hatnub.

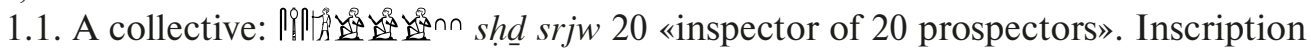
Hatnub Gr. $3.12^{129}$ from «year of the $14^{\text {th }}$ occasion (of the counting)» i.e. $27 / 28^{\text {th }}$ regnal

${ }^{123}$ Gardiner, Peet, Černý 1952, pl. 7; Černý 1955, 65; Edel 1983, 158-163, Abb. 1a-b. Tallet 2012a, I, 29, II, 10; 2018, 305 (CCIS8).

124 The false door and reliefs in the tomb of his father $t j$ (Saqqara D22; PM III.2 1981, 469-478; Steindorff 1913, Taf. 18-19; Épron, Daumas, Goyon 1939, pl. 17, 19-20, 44, 63), as well as the bases of statues Cairo CG 305 and CG 313 (Borchardt 1911, 182, 184). Dating: $n j-w s r-r^{c}-m n-k 3 w-h r$.

${ }^{125}$ Cf. Nuzzolo 2018, 384-385 [70].

${ }^{126}$ Fischer 1968, 101, n. 458; 1996b, 10 (j); edict Coptus R (Cairo JdE41894: Weill 1912, 59-67, pl. 4 [1], 9; Urk. I, 1932-1933, 306.2-8; Goedicke 1967, 214-215, 222, Abb. 28); The Instruction for king Merikara E85-87 / M VI.5-6 (Quack 1992, 182) et al.

${ }^{127}$ Urk I, 65.17 = Brovarski 2000, 108-109, pl. 75-78a, fig. 23; text fig. 4; Diego Espinel 2011, 60, fig. 8 (no. 120); Edel 2008, I, 50-51, 243 (Abb. 32), Text 59, Taf. $9=$ Seyfried 2005, 314-318 (tomb QH 26) et al.

${ }^{128}$ The main accounts of sources about the title $\operatorname{sh} \underline{\underline{d}} \operatorname{sr}(j) w$ : Jones 2000, 966-967 (3564-3565) («inspector of $s r$-officials/magistrates»); Hannig 2003, 1189-1190. Data about $s h d w s r(j) w$ in the Sinai inscriptions are tabulated in Tallet 2018, 135.

${ }^{129}$ Anthes 1928, 20, Taf. 10-10A. This title is usually read as of shd srjw (Anthes 1928, 20; Eichler 1993, 43 (39) et al.). This reading appeared because of a 
year of king $h r n t r j-h^{\complement} w\left(p p j\right.$ II $\left.n f r-k 3-r^{\Upsilon}\right)$. The numeral 20 after the title, with the determinative A1 pl. instead of the name, look strange, although it is understandable in the standard name list of the crew.

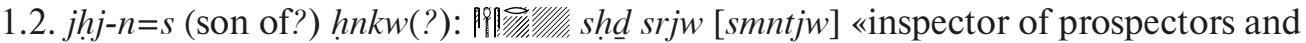
[guides]». Inscription Wadi Hammamat M $151^{130}$. E. Eichler ${ }^{131}$ identified the author of the inscription $j h j-n=s^{132}$ with ${ }^{\top} n h-m r j-r^{r} / j h j-n=s$ of stela Cairo CG $1483^{133}$, however his equating is absolutely arbitrary. ${ }^{\top} n h-m r j-r / j h j-n=s$ was an important nobleman, «overseer of the (department) of all the works of the king» (jmj-r3 k3t nbt nt nswt), but jhj-n=s from Wadi Hammamat was only the commander of an expedition crew.

1.3. $j d[w$ ? ]: Villan gypsum Ayn Soukhna CCIS250 ${ }^{134}$.

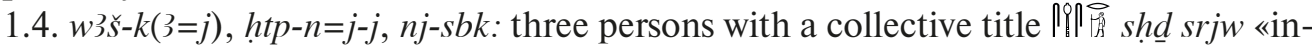
spector of prospectors». Inscription Sinai $13^{135}$. All the three as holders of this office are not attested in other sources.

1.5. htp: 阶展通 shd srjw «inspector of prospectors». Inscription Ayn Soukhna CCIS214 ${ }^{136}$.

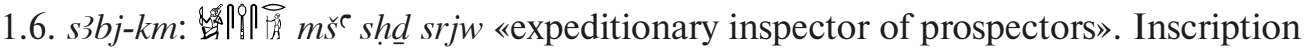
Sinai $20^{137}$. The ideogram of the soldier with the meaning $m s^{\complement}$ «army, expedition, campaign» stands in front of the title. The title is written in accordance with the habitual standard for the titles with the element $p r-\mathrm{C}_{3}$, which as a stand-alone title simply means «palace attendant» and in most other cases is put in front of the title as the place of service, for example, as in the title rh nswt pr-3 «king's acquaintance of the palace». Nevertheless, it should be recognized that the ideogram $m s^{\complement}$ herein means «campaign, march» rather than

mistake in the transcription (cf. Anthes 1928, 20, Anm. 12: he believes that it is the drawing that is incorrect, and not the transcription). Although in the facsimile of the hieratic inscription made by G. Möller it is the sign $h \underline{d}$ which is obvious and not $m$, everybody is oriented to the hieroglyphic transcription which results in a mistake. Based on this uncertain reading, M.A. Lebedev devoted half a page of the text to description of activities of the expedition members with the title sms.w which he interpreted as «foremen of (carpenter shops)» (Lebedev $2015,84,419)$ although they were not mentioned in the expedition inscriptions at all.

${ }^{130}$ Couyat, Montet 1912, 92, pl. 34. Dating: $8^{\text {th }}$ Dynasty.

${ }_{131}$ Eichler 1993, 75.

${ }^{132}$ To the reading of the name $j h j-n=s$ : Fischer 1996a, 60-61; cf. Scheele-Schweitzer 2014, 260 [451]: Jh.y-n=s (?)/N(.j)-sw-Jh.y (?) «ein Jh.y für sie! (?)/ er gehört dem Ihi (?)».

${ }^{133}$ PM III.2 1981, 586; Borchardt 1937, 174-175, Bl. 39. Dating: $m r j . n-r^{r}-p p j$ II.

${ }^{134}$ Tallet 2012a, I, 227, II, 161-162; 2018, 305; 2020, 6 [Doc. 2], pl. 4-5. Dating: [rnpt-zp] $73 b d 4$ smw hrw 4 «[year] of the $7^{\text {th }}$ occasion (of the counting), $4^{\text {th }}$ month of the harvest season, $4^{\text {th }}$ day», i.e. $13 / 14^{\text {th }}$ regnal year of king $d d-k 3-r^{c} j z z j$.

${ }^{135}$ Weill 1904, 109-116 (11-12); Urḱ. I, 1932-1933, 56.6-8; Gardiner, Peet, Černý 1952, pl. 7; Baines, Parkinson 1997, 9-27, fig. 1; Tallet 2018, 304. Wadi Maghara. Dating: rnpt m-ht $z p 4$ tnwt jhw ${ }^{`} w t n b$ «year after the 4th occasion of the counting of all the large and small cattle» i.e. $8 / 9^{\text {th }}$ regnal year of king $d d-k 3-r^{\complement} j z z j$.

${ }^{136}$ Tallet 2012a, I, 197-198, II, 137; 2012b, 109, 114, fig.5; 2020, 15-16 [Doc. 6], pl. 14. Dating: late $5^{\text {th }}$ or $6^{\text {th }}$ Dynasties. The transcription by P. Tallet: pip $p^{2}$ 惫 Judging from the photograph, the usual determinative $\mathrm{A} 1$ follows the sign $s r$, and the small sign $h 3 s t$ is absent at all.

${ }^{137}$ PM VII, 342; Gardiner, Peet, Černý 1952, pl. 10; Černý 1955, 65; Edel 1983, 165. Wadi Maghara. Dating: $j z z j-6^{\text {th }}$ Dynasty. Cf. Eichler 1993, 36. 
«army». Similar method was used in the title of $j d w$ : overseer of prospectors» ${ }^{138}$, which is also attested with the sign $m \check{s}^{\complement}$ 《army» in the postposition and determinative A1 in the title of htp:

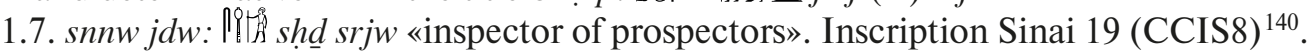
With high probability he is identical with [shd $\underline{\text { ? }]} \operatorname{srjw} j d[w ?](1.3)^{141}$.

1.8. k3j: sha srjw smntjw «inspector of prospectors and guides». Inscriptions Wadi Hamma-

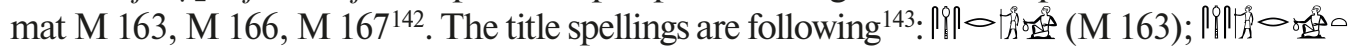
(M 167, M 166). k3j also held offices of hrp 'prw nfrw «captain of a squad of recruits» and jmj-r3 $10 \mathrm{wj}$ « «overseer of ten of a boat (i.e. 10 boatmen)» (Wadi Hammamat M 165).

2. Interpretation of the title $\operatorname{sh} \underline{\underline{d}} \operatorname{srj}(w)$ in tomb inscriptions depends solely on the context, namely on the accompanying titles clarifying the sphere of activity and other indirect criteria. In most cases the title srjw should be understood as «auditors, fiscal agents, informers», although it could also be the expedition members as shown in the case of the offering basin from tomb G 1111. Prosopography of bearers of the title $\operatorname{sh} \underline{d} \operatorname{srj}(w)$ on the monuments from the Memphite region include the following persons:

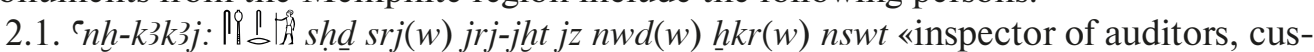
todian of property of the division of unguents of the (department of) king's regalia» ${ }^{144}$. That functionary was an official of the department of king's regalia $(h k r(w) n s w t)$ which was divided into two offices $(j z w j)^{145}$. One of them included a division of $n w d(w)$ unguents $^{146}$, where $~ n h-k 3 k 3 j$ worked as a petty clerk, performing, in particular, the functions of an «inspector of auditors», which is not surprising given the value of products manufactured at the department establishments.

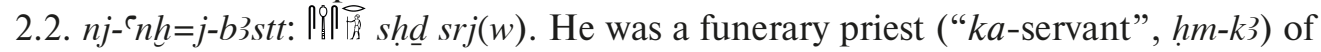
the tomb owner, $\underline{d} f 3 w$, who held the office of $j m j-r 3$ prwj-h $\underline{d} w j$ «overseer of the double silver-house» ${ }^{147}$. That nobleman, who was the head of the entire finance department, appointed his proper servant $n j-{ }^{\complement} n h=j-b 3 s t t$ a clerk at government service; his status was the same as that of ${ }^{`} n h-k 3 k 3 j(2.1)$.

${ }^{138}$ Inscription Sinai 21 (CCIS9). Gardiner, Peet, Černý 1952, pl. 10; Černý 1955, 65; Edel 1983, 165-169, Abb. 3a-b; Tallet 2012a, I, 30, II, 10; 2018, 305. Wadi Maghara. Dating: jzzj(?). ${ }^{139}$ CCIS13. Tallet 2012a, II, 12; cf. ibidem, I, 32 (the determinative A1 is absent from the transcription). Wadi Maghara. Dating: 2nd half of $5^{\text {th }}-6^{\text {th }}$ Dynasties.

${ }^{140}$ Gardiner, Peet, Černý 1952, pl. 9; Černý 1955, 65; Edel 1983, 158-163, Abb. 1a-b; Tallet 2012a, I, 29, II, 10; 2018, 305. Wadi Maghara. Dating: $\underline{d} d-k 3-r^{r}$.

141 Tallet 2018, 108-109.

${ }^{142}$ Couyat, Montet 1912, 93-94. Dating: $6^{\text {th }}$ Dynasty.

${ }^{143}$ There are no photographs of the inscriptions in Couyat \& Montet's publication. I used photographs available on the website ancienegypte.fr/ouadi_hammamat/page2.htm (33.jpg, 41.jpg).

${ }^{144}$ False door Cairo CG 1424 (PM III.2 1981, 458; Borchardt 1937, 105. Saqqara, tomb

D31). Dating: first half of the $5^{\text {th }}$ Dynasty.

145 Bogdanov 2017a, 83-84.

${ }^{146}$ About the element $n w d w$ «unguents» in the titles see Koura 2003, 74-76.

147 The false door in tomb D25: Mariette 1889, 254; Petrie, Murray 1952, pl. 14. Saqqara. Dating: $n j-w s r-r^{r}$. 
2.3. $n f r-j h j$ : 饮原 $s h \underline{d} \operatorname{srj}(w)^{148}$. He was also holding the title $r h$ nswt «king's acquaintance» which was the lowest indicator of nobility. Occupation of $n f r$-jhj remains uncertain.

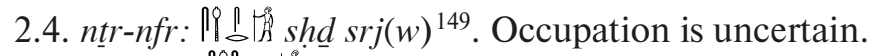

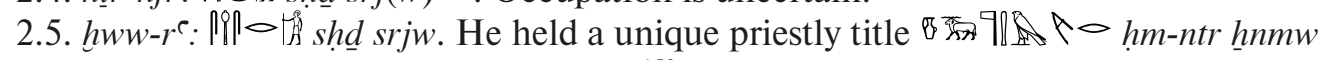
$m r j \mathrm{hr}$ «priest of Khnum beloved by Horus» ${ }^{150}$. Occupation is uncertain.

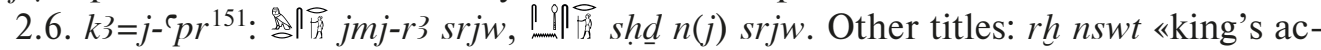
quaintance», skd $n w j 3$ «rower of a boat» ${ }^{152},[\ldots]$ sr $n \check{s}[\ldots]$ ? wj3 «[...] boat», $n s t-h n t(j) t$ «upper throne», $w \underline{d}^{\top}-m d w m$ hwt-[wrt] «judge in the Hall of Justice» ${ }^{153}, w \underline{d}-m d w n(j)$ $h r j(w)$ - $w d \underline{d} b w$ «giver of orders of the (department of) distribution» ${ }^{154}, j m j-r 3 m \check{s}^{\ulcorner}$«general», $j m j-r 3$ šnwt «overseer of kraal» ${ }^{155}$. This person combined naval, military and judicial titles in his titulary. According to the naval titles $k 3=j$ - $P p r$, I tend to interpret the group $s r j w$ on his relief as the expedition members, prospectors.

\section{Dubia:}

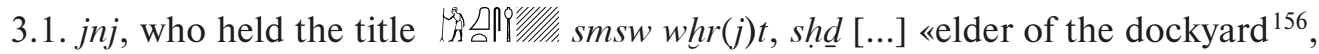
inspector [...]» ${ }^{157}$. The reading $\operatorname{shd} \operatorname{sr}(w) k[n b] t$ «inspector of the law [court] $\operatorname{sr}(w)$-officials (?)» indicated by the publisher is incorrect.

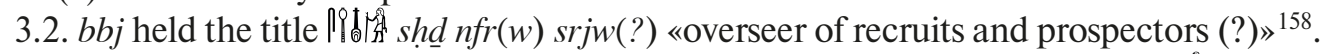
Possibly the sign $s r$ happened to be here by chance instead of the determinative ${ }^{\circ}$ 《child»

${ }^{148}$ False door Saqqara Magazine no. 19545 (El-Tonssy, Yossef 2014, 450-451, Taf. 17, fig. 2). Dating: first half of the $5^{\text {th }}$ Dynasty.

149 The reliefs Cairo CG 1451; CG 1529 (PM III.1 1974, 308; Borchardt 1937, 137, 228, B1. 34). Giza. Dating: late $4^{\text {th }}$ Dynasty.

${ }^{150}$ Two blocks in the wall of tomb G 2230+2231 (Roth 1995, 160, pl. 118c, 199; www. gizapyramids.org: A8221_NS). Dating: wnjs.

${ }^{151}$ Lintel from tomb $\overline{\mathrm{G}} 8853$ (PM III.1 1974, 262-263; Hassan 1936, 155, 157, fig. 185). Dating: second half of the $5^{\text {th }}$ Dynasty.

152 Jones 2000, 981 (3621); Hannig 2003, 1248.

153 Jones 2000, 411 (1511).

154 Jones 2000, 407-408 (1500).

${ }^{155}$ According to Selim Hassan's transcription and interpretation (Hassan 1936, 155, 157), the title means «the overseer of the granary», which is incorrect. The title is to be read jmj-r $r$ šnw «overseer of kraal» (Jones 2000, 252-253 (914-915); to add the title of $\underline{d} f$ s-nswt (architrave from tomb G 1171: www.gizapyramids.org: C12000_OS) who also held the title hrp 'pr skd(w) jz(t)

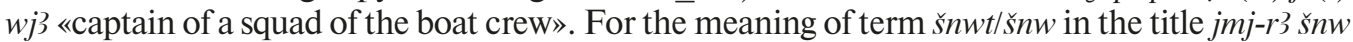
as «kraal, circular camp» of Nubian tribes see Abu Bakr, Osing 1973, 101, 106, 109, 110; Osing 1976a, 135, 137, 155; see also Bogdanov 2014, 7, 14, note 9). There is no reason to confuse «police» $\check{s} n \underline{t}(\check{s} n \underline{t}>\check{s} n t)$ with «squad» $\check{s} n w(t)$. Usage of this term in Egyptian military titles indicates that Nubian soldiers serving in Egyptian army were recruited in units based on their tribal affiliation.

156 Jones 2000, 899-900 (3301); Hannig 2003, 1144.

${ }^{157}$ Fragments of relief Excav. no. 150b/GG/1995 from the tomb of $k 3 r$ Junior (Bárta 2009, 150, 186-187, fig. 6.3.10-6.3.11).

${ }^{158}$ Kuhlmann 2005, 244-246, Abb. 1-4. Dating: rnpt m-hnt zp 12 tn $(w t){ }^{`} w t n b(t)$ «year after the $12^{\text {th }}$ occasion of the counting of all the small cattle» $\left(24 / 25^{\text {th }}\right.$ years of Cheops' reign $)$. 
for the word $n f r w$ «recruits». In another graffito of $b b j$ his title is already given in a more standard form: $s h \underline{d}(w) n f r w$ stp-z3 «overseer(s) of recruits of security» jj-mrj and $b b j{ }^{159}$.

TO THE IDENTIFICATION OF $s h \underline{\underline{d}} s r j w$ «OVERSEER OF PROSPECTORS» $j w w-n m t j$

It is possible to single out two persons with the name $j w w$-nmtj, serving in the administration of $s r j w$, among the authors of the inscriptions. I present their data according to prosopography of the bearers of the name $j w w-n m t j$ given above:

2.3. $j w w-n m t j$. Title: $j m j-r 3 s r(j w)$ «overseer of prospectors». Inscription Sinai 13 from rnpt $m$ - ht zp 4 tnwt jhw ${ }^{`} w t ~ n b$ «year after the $4^{\text {th }}$ occasion of the counting of all the large and small cattle», i.e. $8^{\text {th }} / 9^{\text {th }}$ regnal year of king $\underline{d} d-k 3-r^{e} j z z j$.

2.8. jww-nmtj. Title: jmj-r3 10 srjw smntjw «overseer of ten prospectors and guides». Graffito in Gebel Abrak (Eastern desert).

Discrepancies in the ranks $j m j-r 3 / s h \underline{d}$ «overseer/inspector» are non-essential in this case. Two cases of combination of these ranks in the sphere of srjw corporation can be distinguished: 1 . In the titulary of $k 3=j-{ }^{-} p r$ who mentions the titles $\left.j m j-r\right\}$ srjw and $s h \underline{d}$ $n(j)$ srjw in his own tomb. 2. According to P. Tallet ${ }^{160}, j d w$ (or snnw jdw) mentioned in inscriptions Sinai 19 (CCIS8), Sinai 21 (CCIS9), Sinai 22 (CCIS7) ${ }^{161}$ and CCIS250 is one and the same person, a member of the expedition to the Sinai under the reign of king $\underline{d} d-k 3-r^{\ulcorner} j z z j$. Therefore, he held the offices of $s h \underline{d} \operatorname{srjw}$ (mentioned in CCIS8 and CCIS250) and jmj-r3 srjw (mentioned in CCIS9) at the same time.

There is nothing worth saying about jww-nmtj of the Abrak inscription; besides, it is difficult to date it exactly. As for jww-nmtj (2.3) of inscription Sinai 13, nothing prevents this identification. Almost certainly, this official is identical with the owner of the offering basin from tomb G 1111, this is why the tomb should also be dated to the reign of $d d-k 3-r^{\ulcorner} j z z j$.

Since long, inscription Sinai 13 has attracted great attention from many researchers owing to its unusual content ${ }^{162}$. The list of members of the expedition to the turquoise mines presented therein includes the preamble which is often considered as the first evidence on the divine oracle in Egypt. According to this text, the expedition to the Sinai was inspired by finding the god's assignment on the precious stone in the broad court of the temple $n h n-r{ }^{\odot}$ «Stronghold of the Sun», the Sun temple of king $w s r-k 3=f$. The offering basin from tomb G 1111 may prove to be the first monument belonging to a member of that expedition - overseer and inspector of prospectors-sr $(j w) j w w-n m t j$.

\section{References}

Abdel-Raziq, A. 2017: An unpublished lintel of Ahmose-Nebpehtyre from El-Atâwla. Journal of the American Research Center in Egypt 53, 47-55.

Abu Bakr, A.M., Osing, J. 1973: Ächtungstexte aus dem Alten Reich. Mitteilungen des Deutschen Archäologischen Instituts. Abteilung Kairo 29, 97-133.

Adams, M.D. 2010: The stela of Nakht, son of Nemty: contextualizing object and individual in the funerary landscape at Abydos. In: Z. Hawass, J. Houser Wegner (eds.), Millions of jubilees: studies in honor

${ }^{159}$ Kuhlmann 2005, 247-251, Abb. 5.

160 Tallet 2018, 108-109.

161 Tallet 2012a, I, 28, II, 9; 2018, 305. Wadi Maghara.

${ }^{162}$ Literature review: Baines, Parkinson 1997, 10-11; see also Kammerzell 2001, 153-164. 
of David P. Silverman. Vol. I. (Supplément aux Annales du Service des Antiquités de l'Egypte, 39). Le Caire, 1-25.

Andreu, G. 1997: La fausse-porte de Nykarê, Cleveland Museum of Art 64.91. In: C. Berger, B. Mathieu (éd.), Études sur l'Ancien Empire et la nécropole de Saqqâra dédiées à Jean-Philippe Lauer. T. I. (Orientalia Monspeliensia, 9). Montpellier, 21-30.

Anthes, R. 1928: Die Felseninschriften von Hatnub: nach den Aufnahmen Georg Möllers. (Untersuchungen zur Geschichte und Altertumskunde Aegyptens, 9). Leipzig.

Assmann, J. 1999: Ägyptische Hymnen und Gebete: übersetzt, kommentiert und eingeleitet. 2. Aufl. Freiburg (Schweiz)-Göttingen.

Bailleul-LeSuer, R.F. 2016: The Exploitation of Live Avian Resources in Pharaonic Egypt: a Socio-Economic Study. PhD Diss. University of Chicago. URL: oi.uchicago.edu/sites/oi.uchicago.edu/files/uploads/shared/docs/Research_Archives/Dissertations/Rozenn\%20Dissertation\%20052516.pdf; дата обращения: 14.04.2021.

Baines, J., Parkinson, R.B. 1997: An Old Kingdom record of an oracle? Sinai inscription 13. In: J. van Dijk (ed.), Essays on Ancient Egypt in Honour of Herman te Velde. (Egyptological Memoirs, 1). Groningen, 9-27.

Barbotin, Chr. (ed.) 2020: Collection égyptienne: Musée Granet, Aix-en-Provence. $2^{\mathrm{ème}}$ éd., corrigée, révisée et augmentée. Aix-en-Provence.

Bárta, M. 2009: Abusir XIII: Abusir South 2. Tomb Complex of the Vizier Qar, his Sons Qar Junior and Senedjemib, and Iykai. Prague.

Barta, W. 1963: Die altägyptische Opferliste von der Frühzeit bis zur griechisch-römischen Epoche. (Münchner Ägyptologische Studien, 3). Berlin.

Barta, W. 1968: Aufbau und Bedeutung der altägyptischen Opferformel. (Ägyptologische Forschungen, 24). Glückstadt.

Baud, M. 1999: Famille royale et pouvoir sous l'Ancien Empire égyptien. T. I-II. Le Caire.

Berlev, O.D. 1969: ['Falcon in boat', a hieroglyph and a god]. Vestnik drevney istorii [Journal of Ancient History] $1,3-30$.

Берлев, О.Д. «Сокол, плывущий в ладье»: иероглиф и бог. ВДИ 1, 3-30.

Berman, L.M., Bohač, J.K. 1999: Catalogue of Egyptian art: the Cleveland Museum of Art. New York.

Bland, L., Malek, J. 1977: Nemtywer, the beholder of the beauty of his lord (Ashmolean Mus. 1885.504). Orientalia Lovaniensia Periodica 8, 119-123. http://proxy.library.spbu.ru:3829/ReferenceExport. aspx?id=19979

Boeser, P.A.A. 1909: Die Denkmäler der Zeit zwischen dem Alten und Mittleren Reich und des Mittleren Reiches 1. Abteilung: Stelen. (Beschreibung der aegyptischen Sammlungen, 2.1). Haag.

Bogdanov, I.V. 2014: [The administrative hierarchy in the Old Kingdom Egypt]. Shidnij svit [The World of the Orient $]$ 4, 5-18.

Богданов, И.В. Должностная иерархия в Египте эпохи Древнего царства. Східний світ 4, 5-18.

Bogdanov, I.V. 2017a: [Crowning and economy: aspects of bureaucratic consciousness in the Old Kingdom Egypt]. In: I.F. Popova, I.V. Bogdanov (eds.), Strany i narody Vostoka. Vyp. 37. Gosudarstvo na Vostoke [Countries and Peoples of the East. Issue. 37. The State in the East]. Moscow, 5-120.

Богданов, И.В. Коронация и экономика: аспекты бюрократического сознания в Египте эпохи Древнего царства. В сб.: И.Ф. Попова, И.В. Богданов (ред.), Страны и народы Востока. Вып. 37. Государство на Востоке. М., 5-120.

Bogdanov, I.V. 2017b: Relief of wnwj (tomb G 2465): from Giza for sale (Tab. VIII-IX). Orientalia 86 (2), $164-180$.

Bogdanov, I.V. 2018: New relief fragments from the tomb of the seafarer jnj. Chronique d'Égypte 93 (186), $227-247$.

Bogdanov, I.V. 2019: The Old Kingdom evidence on the toponym hntj-š "Lebanon". Ägypten und Levante 29, 125-148.

Bogdanov, I.V., Bolshakov, A.O. 2004: [The Old Kingdom relief of $h w(j)-w(j)-n f r$ from the Hermitage collection and the tomb G 2098]. Vestnik drevney istorii [Journal of Ancient History] 2, 12-32.

Богданов, И.В., Большаков, А.О. Староегипетский рельеф $h w(j)-w(j)-n f r$ в собрании Эрмитажа и гробница G 2098. ВДИ 2, 12-32.

Bolshakov, A.O. 2005: Studies on Old Kingdom Reliefs and Sculpture in the Hermitage. (Ägyptologische Abhandlungen, 67). Wiesbaden. 
Borchardt, L. 1911: Statuen und Statuetten von Königen und Privatleuten. Teil I. Text und Tafeln zu Nr. 1-380. (CG, no. 1-1294). Berlin.

Borchardt, L. 1937: Denkmäler des Alten Reiches (ausser den Statuen) im Museum von Kairo. Teil I. Text und Tafeln zu Nr. 1295-1541. (CG, no. 1295-1808). Berlin.

Bosticco, S. 1959: Museo Archeologico di Firenze. Vol. I. Le stele egiziane dall'Antico al Nuovo Regno. Roma.

Brovarski, Ed. 2000: Giza Mastabas 7. The Senedjemib Complex. Pt. 1. The Mastabas of Senedjemib Inti ( $G$ 2370), Khnumenti (G 2374), and Senedjemib Mehi ( $G$ 2378). Boston.

Brovarski, Ed. 2016: Some Monuments of the Old Kingdom in the Field Museum of Natural History - Chicago. (Bibliothèque d'étude, 166). Le Caire.

Brovarski, Ed. 2018: Naga ed-Dêr in the First Intermediate Period. Atlanta.

Bruyn, P. de 1958: Falcon graffiti in the Eastern desert. Journal of Egyptian Archaeology 44, 97-98.

Budge, E.A.W. 1912: Hieroglyphic Texts from Egyptian Stelae, \&c., in the British Museum. Pt. II. London.

Budge, E.A.W. 1913: Hieroglyphic Texts from Egyptian Stelae, \&c., in the British Museum. Pt. IV. London.

Cannuyer, Chr. 2010: La girafe dans l'Égypte ancienne et le verbe $\Gamma_{0} \mathbf{n}:$ étude de lexicographie et de symbolique animalière. (Acta Orientalia Belgica, Subsidia IV). Bruxelles.

Černý, J. 1955: The Inscriptions of Sinai from Manuscripts of Alan H. Gardiner and T. Eric Peet. Part II. Translations and Commentary. (EES, 45). London.

Clère, J.J. 1935-1938: Le fonctionnement grammatical de l'expression pri hrw en ancien égyptien. In: Mélanges Maspero I: Orient ancien, fasc. 2. (MIFAO, 66). Le Caire, 753-797.

Couyat, J., Montet, P. 1912: Les inscriptions hiéroglyphiques et hiératiques du Ouâdi Hammâmât. (MIFAO, 34). Le Caire.

Daoud, Kh.A. 2005: Corpus of Inscriptions of the Herakleopolitan Period from the Memphite Necropolis: Translation, Commentary, and Analyses. (BAR International Series, 1459). Oxford.

Diego Espinel, A. 2006: Etnicidad y territorio en el Egipto del Reino Antiguo. Barcelona.

Diego Espinel, A. 2011: Blocks from the Unas causeway recorded in Černý's notebooks at the Griffith Institute, Oxford. In: N. Strudwick, H. Strudwick (eds.), Old Kingdom, New Perspectives: Egyptian Art and Archaeology 2750-2150 BC. Oxford, 50-70.

Diego Espinel, A. 2014: Surveyors, guides and other officials in the Egyptian and Nubian deserts: epigraphic and historical remarks on some Old Kingdom graffiti. Revue d'égyptologie 65, 29-48.

Edel, E. 1955-1964: Altägyptische Grammatik I-II. Roma.

Edel, E. 1983: Beiträge zu den ägyptischen Sinaiinschriften. Göttingen, 158-185.

Edel, E. 2008: Die Felsgräbernekropole der Qubbet el Hawa bei Assuan. I. Abteilung. Bd. I-III. Die Architektur, Darstellung, Texte, archäologischer Befund und Funde der Gräber QH $24-Q H$ 209. Paderborn.

Eichler, E. 1993: Untersuchungen zum Expeditionswesen des ägyptischen Alten Reiches. Wiesbaden.

El-Tonssy, M.A., Yossef, M. 2014: Two unpublished false doors from Saqqara. Studien zur Altägyptischen Kultur 43, 439-455.

Épron, L., Daumas, F., Goyon, G. 1939: Le tombeau de Tî: dessins et aquarelles. (MIFAO, 65). Le Caire.

Fakhry, A. 1961: The Monuments of Sneferu at Dahshur. Vol. II. The Valley Temple. Pt. 2. The Finds. Cairo.

Fischer, H.G. 1960: Old Kingdom inscriptions in the Yale Gallery. Mitteilungen des Instituts für Orientforschung 7 (3), 299-315.

Fischer, H.G. 1964: Inscriptions from the Coptite Nome. Dynasties VI-XI. Roma.

Fischer, H.G. 1968: Dendera in the Third Millennium BC Down to the Theban Domination of Upper Egypt. Locust Valley (NY).

Fischer, H.G. 1974: The mark of a second hand on ancient Egyptian antiquities. Metropolitan Museum Journal 9, 5-34.

Fischer, H.G. 1976: (Rev.:) B. Porter, R.B. Moss, assisted by E.W. Burney. Topographical Bibliography of Ancient Egyptian Hieroglyphic Texts, Reliefs and Paintings. Vol. III. Memphis. Pt. I: Abû Rawâsh to Abûșîr. $2^{\text {nd }}$ ed., rev. and aug. by Jaromír Málek. Oxford, 1974. Bibliotheca Orientalis 33, 21-24.

Fischer, H.G. 1985: More about the smntjw. Göttinger Miszellen 84, 25-32.

Fischer, H.G. 1987-1988: A parental link between two Thinite stelae of the Heracleopolitan period. Bulletin of the Egyptological Seminar of New York 9, 15-23.

Fischer, H.G. 1996a: Egyptian Studies III. Varia Nova. New York.

Fischer, H.G. 1996b: The Tomb of Ip at El Saff. New York.

Fischer, H.G. 1997: Quelques particuliers enterrés à Saqqâra. In: C. Berger, B. Mathieu (éd.), Études sur l'Ancien Empire et la nécropole de Saqqâra dédiées à Jean-Philippe Lauer. T. I. (Orientalia Monspeliensia, 9). Montpellier, 177-189. 
Florès, J. 2015: Les céréales: analyse d'une gestion au protodynastique et sous l'Ancien Empire. (Studien zur Altägyptischen Kultur, Beihefte 17). Hamburg.

Franke, D. 1984: Personendaten aus dem Mittleren Reich (20.16. Jahrhundert v. Chr.): Dossiers 1-796. (Ägyptologische Abhandlungen, 41). Wiesbaden.

Gardiner, A.H. 1957: Hymns to Sobk in a Ramesseum papyrus. Revue d'égyptologie 11, 43-56.

Gardiner, A.H., Peet, T.E., Černý, J. 1952: The Inscriptions of Sinai. Pt.I. Introduction and Plates. $2^{\text {nd }}$ ed. (EES, 36). London.

Gauthier-Laurent, M. 1931: Quelques objets égyptiens du Musée de Langres. Bulletin de l'Institut Français d'Archéologie Orientale 30, 107-125.

Gauthier-Laurent, M. 1933: Une stèle du Moyen-Empire. Revue d'égyptologie 1, 75-80.

Generalverwaltung (ed.) 1913: Ägyptische Inschriften aus den Königlichen Museen zu Berlin. Bd.I. Leipzig.

Goedicke, H. 1967: Königliche Dokumente aus dem Alten Reich. (Ägyptologische Abhandlungen, 14). Wiesbaden.

Goelet, O. Jr. 1982: Two Aspects of the Royal Palace in the Egyptian Old Kingdom. PhD Thesis. Columbia University.

Graefe, E. 1980: Studien zu den Göttern und Kulten im 12. und 10. oberägyptischen Gau (insbesondere in der Spät- und griechisch-römischen Zeit). Freiburg.

Gundacker, R. 2010: Eine besondere Form des Substantivalsatzes: mit besonderer Rücksicht auf ihre dialektale und diachrone Bedeutung. Lingua Aegyptia 18, 47-117.

Gundacker, R. 2013: Die Eigennamen der Könige der IV. Dynastie. Ihre Struktur und Bedeutung gemäß ägyptischen und griechischen Graphien. Lingua Aegyptia 21, 35-130.

Gundacker, R. 2014: Die Namen \#Substantiv $-\$ d \underline{d} m=f \#$ im Alten Reich. Über die onomasiologische Vielfalt hinter der graphischen Einheit. Lingua Aegyptia 22, 61-144.

Hamza Awad, Kh.A. 2006: Untersuchungen zu den Beamtentiteln des $N j-k 3-R^{\complement}$ anhand der Scheintür Nr. 64.91 im Cleveland Museum of Art. In: G. Moers, H. Behlmer, K. Demuß, K. Widmaier (eds.), jn.t dr.w: Festschrift für Friedrich Junge. Bd.I. Göttingen, 73-87.

Hannig, R. 2003: Ägyptisches Wörterbuch I. Altes Reich und Erste Zwischenzeit. (Hannig-Lexica, 4). Mainz am Rhein.

Hannig, R. 2006: Ägyptisches Wörterbuch II. Mittleres Reich und Zweite Zwischenzeit. (Hannig-Lexica, 5). Mainz am Rhein.

Hassan, S. 1936: Excavations at Gîza. Vol. II. 1930-1931. Cairo.

Hayes, W.C. 1951a: Inscriptions from the Palace of Amenhotep III. Journal of Near Eastern Studies 10 (1), $35-56$.

Hayes, W.C. 1951b: Inscriptions from the Palace of Amenhotep III. Journal of Near Eastern Studies 10 (2), 82-112.

Hintze, F., Reineke, W.F. 1989: Felsinschriften aus dem sudanesischen Nubien. Bd. I-II. (Publikation der Nubien-Expedition 1961-1963, 1). Berlin.

Hodjash, S., Berlev, O. 1982: The Egyptian Reliefs and Stelae in the Pushkin Museum of Fine Arts, Moscow. Leningrad.

Ilin-Tomich, A. 2017: From Workshop to Sanctuary: the Production of Late Middle Kingdom Memorial Stelae. (Middle Kingdom Studies, 6). London.

James, T.G.H. 1974: Corpus of Hieroglyphic Inscriptions in the Brooklyn Museum. Vol. I. From Dynasty Ito the End of Dynasty XVIII. Brooklyn (NY).

Jones, D. 2000: An Index of Ancient Egyptian Titles, Epithets and Phrases of the Old Kingdom. Vol. I-II. Oxford.

Junker, H. 1943: Gîza VI. Die Maștaba des nfr (Nefer), kdfjj (Kedfi), k3hiff (Kahjef) und die westlich anschließenden Grabanlagen. Wien-Leipzig.

Junker, H. 1947: Gîza VIII. Der Ostabschnitt des Westfriedhofs. 2. Teil. Wien.

Kaiser, W., Dreyer, G., Gempeler, R., Grossmann, P., Haeny, G., Jaritz, H., Junge, Fr. 1976: Stadt und Tempel von Elephantine. 6. Grabungsbericht. Mitteilungen des Deutschen Archäologischen Instituts, Abteilung Kairo 32, 67-112.

Kamal El-din, N. 2009: Die Scheintür des Qdw. Bulletin of the Egyptian Museum 6, 19-26.

Kammerzell, F. 2001: “... within the altar of the sun": an unidentified hieroglyph and the construction of the sun temple Nhn-R`w. In: O. Goldwasser, D. Sweeney (eds.), Structuring Egyptian Syntax: a Tribute to Sarah Israelit-Groll. (Lingua Aegyptia, 9). Göttingen, 153-164.

Kanawati, N. 2013: The mastaba of Kaihai: where the cemeteries of Weserkaf and Teti meet. Études et Travaux 26 (1), 347-362. 
Kaplony, P. 1963: Die Inschriften der ägyptischen Frühzeit. Vol. II. (Ägyptologische Abhandlungen, 8). Wiesbaden.

Kaplony, P. 1981: Die Rollsiegel des Alten Reiches. Vol. II A-B. (Monumenta Aegyptiaca, 3 $3^{\mathrm{A}}-3^{\mathrm{B}}$ ). Bruxelles.

Kitchen, K.A. 1990: Catálogo da Coleçao do Egito Antigo existente no Museu National, Rio de Janeiro / Catalogue of the Egyptian Collection in the National Museum, Rio de Janeiro. Preparado com a colaboraçao da Maria da Conceiçao Beltrao. Vol. I. Texto / Text. Vol. II. Illustraçoes / Plates. Warminster.

Kormysheva, E., Malykh, S., Lebedev, M., Vetokhov, S. 2015: Giza. Eastern Necropolis III. Tombs of Tjenty II, Khufuhotep, and Anonymous Tombs GE17, GE18, GE47, GE48, and GE49. Moscow.

Koura, B. 2003: Oils and fats manufacturing institutions: the names of workshops and titles of workers and officials. In: Chr. Leblanc (éd.), Parfums, onguents et cosmétiques dans l'Égypte ancienne: actes des rencontres pluridisciplinaires tenues au Conseil national de la culture, Le Caire 27-29 avril 2002. (Memnonia, Cahier supplémentaire, 1). Le Caire, 67-79.

Kuhlmann, K.-P. 2005: Der „Wasserberg des Djedefre” (Chufu 01/1): ein Lagerplatz mit Expeditionsinschriften der 4. Dynastie im Raum der Oase Dachla. Mitteilungen des Deutschen Archäologischen Instituts, Abteilung Kairo 61, 243-289.

Labrousse, A., Lauer, J.-Ph., Leclant, J. 1977: Mission archéologique de Saqqara II. Le temple haut du complexe funéraire du roi Ounas. (Bibliothèque d'étude, 73). Le Caire.

Lange, H.O., Schäfer, H. 1902a: Grab- und Denksteine des Mittleren Reichs im Museum von Kairo. Teil I. Text zu No. 20001-20399. (CG, no. 20001-20780). Berlin.

Lange, H.O., Schäfer, H. 1902b: Grab- und Denksteine des Mittleren Reichs im Museum von Kairo. Teil IV. Tafeln. (CG, no. 20001-20780). Berlin.

Lange, H.O., Schäfer, H. 1908: Grab- und Denksteine des Mittleren Reichs im Museum von Kairo. Teil II. Text zu No. 20400-20780. (CG, no. 20001-20780). Berlin.

Lapp, G. 1986: Die Opferformel des Alten Reiches: unter Berücksichtigung einiger späterer Formen. (Sonderschrift, Deutsches Archäologisches Institut, Abteilung Kairo 21). Mainz.

Lebedev, M.A. 2015: Slugi faraona vdali ot Nila: razvitie kontaktov drevneegipetskoy tsivilizatsii s okruzhayushchimi oblastyami v epokhu Drevnego i Srednego tsarstv [Servants of the Pharaoh Far from the Nile: The Development of Contacts of the Ancient Egyptian Civilization with the Surrounding Areas During the Old and Middle Kingdom]. Saint Petersburg.

Лебедев, М.А. Слуги фараона вдали от Нила: развитие контактов древнеегипетской цивилизации с окружающими областями в эпоху Древнего и Среднего иарств. СПб.

Legros, R. 2013: Un cas de fabrication collective à Saqqâra? La table d'offrandes de Setjou. Journal of the American Research Center in Egypt 49, 153-166.

Lehmann, K. 1995: Die Mastaba G 2009 auf dem Westfriedhof von Giza. Magisterarbeit, Universität Heidelberg. URL: http://www.gizapyramids.org/static/pdf\%20library/lehmann_mastaba.pdf; дата обращения: 9.04.2021.

Leitz, Chr. (Hrsg.) 2002: Lexikon der ägyptischen Götter und Götterbezeichnungen. Bd. 4. (Orientalia Lovaniensia Analecta, 113). Leuven-Paris-Dudley.

Lepsius, C.R. 1849-1859: Denkmaeler aus Aegypten und Aethiopien II. Berlin.

Luft, U. 1984: dj.j rh.k. In: F. Junge (Hrsg.), Studien zu Sprache und Religion Ägyptens: zu Ehren von Wolfhart Westendorf, überreicht von seinen Freunden and Schülern. Bd.I. Sprache. Göttingen, 103-111.

Mariette, A. 1889: Les mastabas de l'Ancien Empire. Paris.

Martin-Pardey, E. 1994: Richten im Alten Reich und die $s r$-Beamten. In: B.M. Bryan, D. Lorton (eds.), Essays in Egyptology in honor of Hans Goedicke. San Antonio, 157-167.

Meeks, D. 1998: Année lexicographique: Égypte ancienne. T. I. 1977. T. II. 1978. $2^{\mathrm{ème}}$ éd. Paris.

Moeller, N., Marouard, G. 2020: Excavations on the Old Kingdom settlement at Tell Edfu. The Oriental Institute News \& Notes 244, 10-17.

Moreno García, J.C. 1997: Études sur l'administration, le pouvoir et l'idéologie en Égypte, de l'Ancien au Moyen Empire. (Ægyptiaca Leodiensia, 4). Liège.

Moret, A. 1909: Catalogue du Musée Guimet: galerie égyptienne, stèles, bas-reliefs, monuments divers. (Annales du Musée Guimet, 32). Paris.

Mostafa, M.F. 2014: The Mastaba of צ̌m3j at Nag’ Kom el-Koffar, Qift I: Autobiographies and Related Scenes and Texts. Cairo.

Moussa, A. 1972: Lintels and lower parts of a leaf of a wooden relief-sculptured door of the Old Kingdom from Saqqara. Mitteilungen des Deutschen Archäologischen Instituts, Abteilung Kairo 28, 289-291. 
Müller, M., Schenkel, W., Gomaà, F. 2004: Scharuna I: der Grabungsplatz, die Nekropole, Gräber aus der Alten-Reichs-Nekropole. Bd. I-II. Mainz.

Nilsson, M., Faraman, A., Said, A. 2018: Some rock inscriptions from Gebel el-Silsila. Journal of Egyptian Archaeology 104 (1), 71-79.

Nuzzolo, M. 2018: The Fifth Dynasty Sun Temples: Kingship, Architecture and Religion in Third Millennium BC Egypt. Prague.

Osing, J. 1976a: Ächtungstexte aus dem Alten Reich (II). Mitteilungen des Deutschen Archäologischen Instituts, Abteilung Kairo 32, 133-185.

Osing, J. 1976b: Die Nominalbildung des Ägyptischen. Bd. I-II. (Sonderschrift, Deutsches Archäologisches Institut, Abteilung Kairo 3). Mainz.

Osing, J. 2004: Les graffiti de l'Ancien et du Moyen Empire au Gebel el-Silsila. In: A. Gasse, V. Rondot (eds.), Séhel entre Égypte et Nubie: inscriptions rupestres et graffiti de l'époque pharaonique, actes du colloque international, 31 mai - 1 juin 2002, Université Paul Valéry, Montpellier. (Orientalia monspeliensia, 14). Montpellier, 3-6.

Perdu, O. 2016: Un témoignage inédit sur un grand dignitaire saïte: le précepteur Horirâa (P. VI-X). Revue d'égyptologie 67, 77-140.

Petrie, H.F., Murray, M.A. 1952: Seven Memphite Tomb Chapels. (British School of Archaeology in Egypt and Egyptian Research Account, 65). London.

Piacentini, P. 2002a: Encore sur les scribes des offrandes divines. In: R. Pirelli (éd.), Egyptological essays on state and society. (Serie egittologica, 2). Napoli, 95-109.

Piacentini, P. 2002b: Les scribes dans la société égyptienne de l'Ancien Empire. Vol. I. Les premières dynasties. Les nécropoles memphites. (Études et Mémoires d'Égyptologie, 5). Paris.

Quack, J.F. 1992: Studien zur Lehre für Merikare. (Göttinger Orientforschungen, 4. Reihe: Ägypten, 23). Wiesbaden.

Ranke, H. 1935: Die ägyptischen Personennamen. Bd.I. Verzeichnis der Namen. Glückstadt.

Ranke, H. 1952: Die ägyptischen Personennamen. Bd. II. Einleitung. Form und Inhalt der Namen. Geschichte der Namen. Vergleiche mit andren Namen. Nachträge und Zusätze zu Bd.I. Umschreibungslisten. Glückstadt-Hamburg-New York.

Roth, A.M. 1995: Giza Mastabas. Vol. VI. A Cemetery of Palace Attendants Including G 2084-2099, $G$ 2230+2231, and G 2240. Boston.

Scheele-Schweitzer, K. 2014: Die Personennamen des Alten Reiches. Altägyptische Onomastik unter lexikographischen und sozio-kulturellen Aspekten. Wiesbaden.

Schenkel, W. 1965: Memphis, Herakleopolis, Theben. Die epigraphischen Zeugnisse der 7.-11. Dynastie Ägyptens. (Ägyptologische Abhandlungen, 12). Wiesbaden.

Schindler von Wallenstern, E. 2011: Die Reiher im Alten Ägypten. Ornithologische Betrachtungen und religionsgeschichtliche Bedeutung. Diss. Tübingen. URL: https://publikationen.uni-tuebingen.de/xmlui/handle/10900/46883; дата обращения: 14.04.2021.

Schlögl, H. (Hrsg.) 1978: Geschenk des Nils. Aegyptische Kunstwerke aus Schweizer Besitz: eine Ausstellung des Ägyptologischen Seminars der Universität Basel in Zusammenarbeit mit dem Schweizerischen Bankverein. Basel.

Schulz, R. 1992: Die Entwicklung und Bedeutung des kuboiden Statuentypus: eine Untersuchung zu den sogenannten "Würfelhockern”. Bd. I-II. (Hildesheimer Ägyptologische Beiträge, 33-34). Hildesheim.

Seidlmayer, St.J. 2005: Bemerkungen zu den Felsinschriften des Alten Reiches auf Elephantine. In: St.J. Seidlmayer (Hrsg.), Texte und Denkmäler des ägyptischen Alten Reiches. (Thesaurus linguae aegyptiae, 3). Berlin, 287-308.

Seyfried, K.-J. 2005: Qubbet el Hawa: Stand und Perspektiven der Bearbeitung. In: St.J. Seidlmayer (Hrsg.), Texte und Denkmäler des ägyptischen Alten Reiches. (Thesaurus linguae aegyptiae, 3). Berlin, 309-334.

Simpson, W.K. 1974: The Terrace of the Great God at Abydos: the Offering Chapels of Dynasties 12 and 13. (Publications of the Pennsylvania-Yale expedition to Egypt, 5). New Haven.

Smith, W. St. 1946: A History of Egyptian Sculpture and Painting in the Old Kingdom. London.

Sperveslage, G. 2010: Das Kongruenzverhalten von Adjektiven im Altägyptischen. Lingua Aegyptia 18, 217-251.

Stefanović, D. 2011: The hm.t $n$ t3-wr bbi. Göttinger Miszellen. Beiträge zur ägyptologischen Diskussion 231, 97-100.

Steindorff, G. 1913: Das Grab des Ti. (Veröffentlichungen der Ernst von Sieglin Expedition in Ägypten, 2). Leipzig. 
Strudwick, N.C. 1985: The Administration of Egypt in the Old Kingdom. The Highest Titles and their Holders. London.

Strudwick, N.C. 2005: Texts from the Pyramid Age. (WAW, 16). Atlanta.

Tallet, P. 2012a: La zone minière pharaonique du Sud-Sinaï. I: Catalogue complémentaire des inscriptions du Sinaï. T. I-II. (MIFAO, 130). Le Caire.

Tallet, P. 2012b: New inscriptions from Ayn Soukhna: 2002-2009. In: P. Tallet, El-S. Mahfouz (eds.), The Red Sea in Pharaonic Times: Recent Discoveries along the Red Sea Coast. Proceedings of the Colloquium held in Cairo. Ayn Soukhna 11 $11^{\text {th }}-12^{\text {th }}$ January 2009. (Bibliothèque d'étude, 155). Le Caire, 105-115.

Tallet, P. 2018: La zone minière pharaonique du Sud-Sinaï. III: Les expéditions égyptiennes dans la zone minière du Sud-Sinaï du prédynastique à la fin de la XXe dynastie. (MIFAO, 138). Le Caire.

Tallet, P. 2020: Le matériel inscrit d'Ayn Soukhna (2002-2016): doc. 1 à 71. In: G. Castel, P. Tallet (éd.), Ayn Soukhna IV: le matériel des galeries-magasins. (Fouilles de l'IFAO, 82). Le Caire, 1-119.

Thirion, M. 1985: Notes d'onomastique, contribution à une révision de Ranke $P N$ [4 ${ }^{\mathrm{ème}}$ série]. Revue d'égyptologie 36, 125-143.

Thirion, M. 2003: Notes d'onomastique, contribution à une révision du Ranke $P N$ [12 ${ }^{\mathrm{ème}}$ série]. Revue d'égyptologie 54, 177-190.

Vernus, P. 1971: Noms propres juxtaposés au Moyen Empire. Revue d'égyptologie 23, 193-199.

Vernus, P. 1980: Études de philologie et de linguistique. Revue d'égyptologie 32, 117-134.

Vernus, P. 1986: Le surnom au Moyen Empire: répertoire, procédés d'expression et structures de la double identité du début de la XII dynastie à la fin de la XVII dynastie. (Studia Pohl, 13). Rome.

Vernus, P. 1987: Edfou, du début de la XII dynastie au début de la XVIII dynastie, études philologiques, sociologiques et historiques d'un corpus documentaire de l'Égypte pharaonique. Thèse de doctorat d'État. Paris.

Wassell, B. 1991: Ancient Egyptian Fauna: A Lexicographical Study. Vol. I-II. PhD Diss. University of Durham. URL: http://etheses.dur.ac.uk/1152/; дата обращения: 14.04.2021.

Weeks, K.R. 1994: Mastabas of Cemetery G 6000: including G 6010(Neferbauptah); G 6020 (Iymery); G 6030 (Ity); G 6040 (Shepseskafankh). (Giza Mastabas, 5). Boston.

Weill, R. 1904: Recueil des inscriptions égyptiennes du Sinaï: bibliographie, texte, traduction et commentaire, précédé de la géographie, de l'histoire et de la bibliographie des établissements égyptiens de la péninsule. Paris.

Weill, R. 1912: Les décrets royaux de l'Ancien Empire égyptien: étude sur les décrets royaux trouvés à Koptos au cours des travaux de la Société française des fouilles archéologiques (campagnes de 1910 et 1911) et sur les documents similaires d'autres provenances. Paris.

Wilson, J.A. 1947: The artist of the Egyptian Old Kingdom. Journal of Near Eastern Studies 6 (4), 231-249.

Woodward, S.R., Kanawati, N. 1995: The Tombs of el-Hagarsa, 3. (Australian Centre for Egyptology: Reports, 7). Sydney.

Yoyotte, J. 1975: Les « sementiou » et l'exploitation des régions minières à l'ancien Empire. Communication du 5 juin 1974. Bulletin de la Société Française d'Égyptologie 73, 44-55.

Ziegler, Chr. 1990: Catalogue des stèles, peintures et reliefs égyptiens de l'Ancien Empire et de la Première Période Intermédiaire vers 2686-2040 avant J.-C. Paris.

\section{List of abbreviations}

PM III.1 1974 - Porter, B., Moss, R.B. Topographical Bibliography of Ancient Egyptian Hieroglyphic Texts, Reliefs and Paintings. Vol. III. Memphis. 2nd ed. Pt. 1. Abû Rawâsh to Abûșîr. Oxford.

PM III.2 1981 - Porter, B., Moss, R.B. Topographical Bibliography of Ancient Egyptian Hieroglyphic Texts, Reliefs and Paintings. Vol. III. Memphis. $2^{\text {nd }}$ ed. Pt. 2. Șaqqâra to Dahshûr. Oxford.

PM V 1937 - Porter B., Moss R.B. Topographical Bibliography of Ancient Egyptian Hieroglyphic Texts, Reliefs and Paintings. Vol. V. Upper Egypt: Sites. Oxford.

PM VIII.1 1999 - Malek, J., Magee, D. Miles, E. (eds.), Topographical Bibliography of Ancient Egyptian Hieroglyphic Texts, Statues, Reliefs and Paintings. Volume VIII: Objects of Provenance Not Known. Part I: Royal Statues, Private Statues (Predynastic to Dynasty XVII), Oxford.

PM VIII.32007 - Malek, J., Fleming, E., Hobby, A., Magee, D. (eds.), Topographical Bibliography of Ancient Egyptian Hieroglyphic Texts, Statues, Reliefs and Paintings. Volume VIII: Objects of Provenance Not Known. Part 3: Stelae (Early Dynastic Period to Dynasty XVII). Oxford.

Urk. I 1932-1933 - Sethe, K. (ed.), Urkunden des Alten Reiches. 2. Aufl. (Urkunden des ägyptischen Altertums, Erste Abteilung, 1). Leipzig, 1932-1933.

Wb. - Erman, A., Grapow, H. (Hrsg.), Wörterbuch der ägyptischen Sprache. Bd. I-V. 4. Aufl. Berlin, 1982. 